\title{
Tumbling under the surf: wave-modulated settlement of intertidal mussels and the continuous settlement-relocation model
}

\author{
S. A. Navarrete ${ }^{1, *}$, J. L. Largier ${ }^{2}$, G. Vera ${ }^{1}$, F. J. Tapia ${ }^{1,3}{ }^{3}$ M. Parragué ${ }^{1}$, E. Ramos ${ }^{1}$, \\ J. L. Shinen ${ }^{1}$, C. A. Stuardo ${ }^{3}$, E. A. Wieters ${ }^{1}$ \\ ${ }^{1}$ Estación Costera de Investigaciones Marinas \& Center for Marine Conservation, Pontificia Universidad Católica de Chile, \\ Casilla 114-D, Santiago, Chile \\ ${ }^{2}$ Bodega Marine Laboratory \& Department of Environmental Science and Policy, University of California, Davis, PO Box 247, \\ Bodega Bay, CA 94923, USA \\ ${ }^{3}$ Departamento de Oceanografía \& COPAS Sur-Austral, Universidad de Concepción, Casilla 160-C, Concepción, Chile
}

\begin{abstract}
For many mussel species, the model of planktonic development followed by metamorphosis and settlement in the benthic habitat is complicated by the existence of planktonic post-metamorphic stages and/or pediveliger benthic stages that can relocate after initial settlement. This has led to the long-standing hypothesis of 'primary' settlement from the plankton onto intertidal algal substrate followed by 'secondary' relocation to mussel beds. Here, we investigate settlement of the intertidal mussels Perumytilus purpuratus and Semimytilus algosus in central Chile to test this hypothesis and explore physical drivers. Our results indicate that: (1) these species do not have planktonic post-metamorphic stages, (2) larvae typically arrive to the intertidal zone at a size 80-150 $\mathrm{mm}$ larger than the largest planktonic larva, which based on growth rates, corresponds to a 3-20 d delay, (3) there are no differences in pediveliger sizes between different algal substrates, mussel beds, or artificial collectors, and (4) there is no evidence that larvae metamorphose in the intertidal and grow in alternative habitat before relocation to mussel beds. In 2 summers, daily settlement of both species was tightly and positively associated with wave height, despite large inter-annual variability in wind conditions. Our results reject the primary-secondary settlement hypothesis and support a new settlement model in which, after metamorphosis beyond the surf zone, the negatively buoyant settlers become semi-benthic and readily sink to the bottom. There, they can be transported onshore through the surf-zone by wave-driven near-bed transport. The process of tumbling under the surf may take from a few hours to several days, with larvae arriving at the shoreline in a wide range of sizes at any given time. For some larvae, relocation continues in the intertidal zone for months.
\end{abstract}

KEY WORDS: Cross-shore transport · Larval ecology · Supply side ecology $\cdot$ Rocky shore $\cdot$ Waves

\section{INTRODUCTION}

The passage from a quasi-microscopic planktonic larval stage to a benthic sessile or semi-sessile organism is one of the ecologically most important and developmentally most complex processes in the biology of many marine benthic organisms. In the classical model of their life cycle, planktonic larvae are the primary dispersal stage, where at the end of develop- ment and over a comparatively short time (from hours to a few days), individuals settle on the adult habitat and metamorphose to sedentary juveniles. Over the past few decades, much has been learned about this delicate and short-lived process we call 'settlement' (Keough \& Downes 1982), including knowledge of the biological, chemical, and physical determinants of variability in time and space (see Shanks 1995, Queiroga et al. 2007, Pineda et al. 2010 
for reviews). However, it is known that many invertebrates have a life cycle that is more complex than the 'classical' model, including optional larval stages, pelagic metamorphosis, and even reversals of metamorphosis, which can lead to a protracted and ambiguously defined settlement process (Baker \& Mann 1997, Mizrahi et al. 2014). Many bivalve species, including common mytilid mussels, have life cycles that include prolonged and difficult-to-define settlement periods (Baker \& Mann 1997).

In the mid 1940s, several authors recognized that settlement in Mytilus edulis was not a single, irreversible process (cited by Bayne 1964) but rather that benthic postlarval individuals continued to move after initial settlement. Examining size distributions of pediveliger and benthic postlarvae, Bayne (1964) proposed that $M$. edulis planktonic pediveliger larvae settle primarily on intertidal filamentous algae, where they metamorphose and grow. Upon reaching approximately $1 \mathrm{~mm}$ in size, benthic postlarvae would detach from the algae; partially resuspend in the water column; and disperse some distance away, aided by byssal threads (Baker \& Mann 1997, Buchanan \& Babcock 1997), to settle secondarily on mussel beds, where they grow to juvenile and adult stages. A common adaptation-based explanation for such a settlement pattern was the potential existence of selective pressures for small planktonic larvae to avoid intense competition with adults in the mussel beds. Avoidance of cannibalism by adults has also been suggested as a pressure to avoid larger conspecifics in mussel beds (Porri et al. 2008a). Since Bayne's (1964) work, many studies have tested this 'primary-secondary' hypothesis in different intertidal mussel species and along different coasts of the world, with weak support at best for the original model, but most have evidenced the common occurrence of mobile postlarval stages (McGrath et al. 1988, Hunt \& Scheibling 1995, 1996, Lasiak \& Barnard 1995, McQuaid \& Lindsay 2005, Porri et al. 2006, 2008a, Reaugh et al. 2007, Erlandsson et al. 2008, Bownes \& McQuaid 2009, Le Corre et al. 2013). Resolving how settlement takes place in these species is, unfortunately, laden with logistical difficulties inherent to the type of environment they inhabit, presenting researchers with the challenging task of piecing together disparate fragments of empirical evidence. Synchrony of recruitment pulses or consistency of body size distributions across different intertidal substrates, sometimes examined over timescales of weeks to months and/or including large individuals (juveniles) as 'recruits', have been used as evidence in favor of or against the primary- secondary recruitment model (e.g. McGrath et al. 1988, Reaugh et al. 2007). Regrettably, with few exceptions (McQuaid \& Lindsay 2005), high-frequency observations (e.g. daily) of the arrival of new mussel settlers and of their body sizes, together with examination of the physical processes that can modulate onshore settlement, have not been part of these studies. Here, we attempt to describe the settlement process and its potential drivers for the 2 common intertidal mussel species found along most of the wave-exposed coast of Chile, piecing together evidence from size distributions in multiple habitats, growth rates, sinking velocities, and daily observations of settlement and physical variables over 2 different peak recruitment seasons.

In species for which there is not a strictly planktonic larval stage followed by a definitive sedentary postlarval stage or juvenile, the terminology for the different stages of the life cycle has further confused their study. Baker \& Mann (1997) provide a useful review of this terminology, and based on empirical evidence for several bivalve species, they proposed a classification of larval stages based on their functionality, which is the one followed here. First, after completing the pediveliger development in the plankton, several bivalve species possess a planktonic postmetamorphic stage that either remains in the plankton after metamorphosis or re-enters the plankton after initial settlement somewhere, probably offshore. Drifting in the plankton is aided primarily by long byssus threads (Sigurdsson et al. 1976, Shanks \& Shearman 2011). This 'planktonic postlarva' is distinguishable from the pediveliger larva by its larger size and the absence of a velum and has been readily identified in soft bottom and rocky shore species (see Baker \& Mann 1997 and references therein). We restrict the term 'planktonic postlarva' to a postmetamorphic individual found in the plankton beyond the surf zone. Second, the term 'plantigrade' larva refers to a benthic post-metamorphic stage that creeps, crawls, or tumbles on the substrate and has been observed in most bivalve species. Unlike the planktonic postlarva, the dispersal potential of the plantigrade is rather limited, although they can be found in water samples as the waves and surf move them around. Transition from the plantigrade larva to the juvenile stage is a gradual process involving few visible morphological changes and can occur over several months of benthic life. Not all mussel species have both of these functionally distinct postlarval stages, and to further complicate the matter, it is likely that their occurrence is a phenotypically plastic attribute within a species. Regardless of the potential 
adaptive value of the different larval stages and of the 'primary-secondary' settlement model, a basic understanding of mussel settlement on the rocky shore should differentiate among (1) settlement of pediveliger larvae that have dispersed during their development in the plankton and metamorphosed upon reaching the intertidal zone; (2) settlement of planktonic postlarvae, which may contribute significantly to overall dispersal after metamorphosis and resuspension; and (3) 'secondary' settlement of plantigrade larvae that have already settled on the benthic habitat some short distance away. Identifying and ideally quantifying the importance of these processes is critical to correctly infer transport processes and associated scales of dispersal from settlement observations (McQuaid \& Phillips 2000, Largier 2003, Smith et al. 2009, Pineda et al. 2010, Le Corre et al. 2013) or to assess the magnitude and sources of post-settlement mortality (McQuaid \& Lindsay 2005). In the case of coexisting mussel species, many important interactions may take place at the transition between settlement from the plankton and secondary settlement by plantigrades (Bownes \& McQuaid 2006, Porri et al. 2007).

Along the extensive coast of Chile, the mussels Perumytilus purpuratus and Semimytilus algosus are common in the mid and low intertidal zones of waveexposed platforms (Fernández et al. 2000, Broitman et al. 2001, Navarrete et al. 2008). (Hereinafter, these species are referred to as simply Perumytilus and Semimytilus, respectively.) The competitively dominant Perumytilus forms extensive beds at most sites in central Chile (Paine et al. 1985, Navarrete et al. 2010). While Semimytilus is found at most sites, it is abundant only at a few places. Individuals of both species are reproductive year round, and recruitment is also observed year round, with a peak in summer months (Navarrete et al. 2008). Larval development is completed between 16 and $27 \mathrm{~d}$, and pediveligers metamorphose at a maximum size of 178 and $150 \mu \mathrm{m}$ for Perumytilus and Semimytilus, respectively (Ramorino \& Campos 1979, Garrido 1996). Although there are several studies on settlement and recruitment of these mussel species (Navarrete et al. 2002, 2008, Narváez et al. 2006), no studies have attempted to identify and evaluate the relative importance of primary settlement from the plankton versus movement of benthic plantigrades or which processes might be involved in transport of these individuals. Here, we first looked for the presence of planktonic postlarval stages and examined larval size distribution for both species in day and night plankton surveys conducted in nearshore waters from the surf zone to $4 \mathrm{~km}$ offshore. We then examined the size distribution of settlers in samples collected from intertidal waters, as well as in common intertidal algae and mussel beds reported as mussel recruitment facilitators, and looked for evidence of postsettlement growth in the benthos. Estimates of pediveliger growth rates allowed us to interpret differences in larval size. Finally, using artificial collectors, we conducted daily settlement observations during 2 separate mussel recruitment seasons. This information, together with the monitoring of physical variables measured remotely and in situ, allowed us to provide a mechanistic explanatory hypothesis for larval transport and the settlement process in these species.

\section{MATERIALS AND METHODS}

With the exception of shipboard plankton surveys, all observations for this study were conducted at intertidal sites near the Estación Costera de Investigaciones Marinas (ECIM) and Playa Chica, separated by about $800 \mathrm{~m}$, on the northern tip of Cartagena Bay in central Chile. Plankton surveys took place off El Quisco $\left(33^{\circ} 23^{\prime} 38^{\prime \prime} \mathrm{S}, 71^{\circ} 41^{\prime} 55^{\prime \prime} \mathrm{W}\right)$, located ca. $14 \mathrm{~km}$ north of the ECIM. A summary of the dates and location of observations collected in this study is presented in Table 1.

\section{Larval distribution and size in the plankton}

To determine whether mussel larvae and/or planktonic postlarval stages of these species were found near the coast, we conducted paired day/night surveys on 4 dates (13 December 2007, 4 February 2008, 19 November 2008, 27 November 2008) off El Quisco. Daytime surveys were completed at least $1 \mathrm{~h}$ before sunset, while nighttime surveys did not begin until at least $1 \mathrm{~h}$ after sunset. In December 2007 and February 2008, the daytime survey preceded nocturnal sampling, but in November 2008, the nighttime surveys were conducted first. Ten sampling stations were distributed along 2 transects perpendicular to the coastline and extending from ca. $300 \mathrm{~m}$ to about $2.5 \mathrm{~km}$ offshore (Fig. S1 in the Supplement at www. int-res.com/articles/suppl/m520p101_supp.pdf). The number of stations that were sampled on each cruise varied between dates, depending on ocean and weather conditions. At each station, stratified vertical plankton tows were conducted using a $0.5 \mathrm{~m}$ diameter closing net with $65 \mu \mathrm{m}$ mesh. The sampled strata 
Table 1. Summary of field and laboratory observations. ECIM = Estación Costera de Investigaciones Marinas

\begin{tabular}{|c|c|c|c|c|}
\hline & Information & Sampling date & Location & Sample type/method \\
\hline Plankton & Distribution and larval size & $\begin{array}{l}13 \text { Dec } 2007 \\
04 \text { Feb } 2008 \\
19 \text { Nov } 2008 \\
27 \text { Nov } 2008\end{array}$ & $\begin{array}{l}\text { El Quisco } \\
\text { El Quisco } \\
\text { El Quisco } \\
\text { El Quisco }\end{array}$ & $\begin{array}{l}\text { Stratified plankton nets } \\
\text { Stratified plankton nets } \\
\text { Stratified plankton nets } \\
\text { Stratified plankton nets }\end{array}$ \\
\hline \multirow[t]{3}{*}{ Intertidal } & Larval size distributions & $\begin{array}{l}16 \text { Jan } 2008 \\
5 \text { Dec } 2013 \\
6 \text { Jan } 2014 \\
5 \text { Feb } 2014\end{array}$ & $\begin{array}{l}\text { Playa Chica } \\
\text { Playa Chica } \\
\text { Playa Chica } \\
\text { Playa Chica }\end{array}$ & $\begin{array}{l}\text { Natural intertidal substrates } \\
\text { Natural intertidal substrates } \\
\text { Natural intertidal substrates } \\
\text { Natural intertidal substrates }\end{array}$ \\
\hline & Larval size distributions & $\begin{array}{l}\text { Oct } 2009 \\
\text { Feb } 2010 \\
\text { Mar } 2010\end{array}$ & $\begin{array}{l}\text { ECIM } \\
\text { ECIM } \\
\text { ECIM }\end{array}$ & $\begin{array}{l}\text { Water pumped from intertidal } \\
\text { Water pumped from intertidal } \\
\text { Water pumped from intertidal }\end{array}$ \\
\hline & Daily settlement & $\begin{array}{l}\text { 14 Jan-11 Feb } 2008 \\
\text { 5-16 Dec } 2013 \\
\text { 6-17 Jan } 2014 \\
\text { 5-15 Feb } 2014\end{array}$ & $\begin{array}{l}\text { Playa Chica } \\
\text { Playa Chica } \\
\text { Playa Chica } \\
\text { Playa Chica }\end{array}$ & $\begin{array}{l}\text { Tuffy collectors replaced daily } \\
\text { Tuffy collectors replaced daily } \\
\text { Tuffy collectors replaced daily } \\
\text { Tuffy collectors replaced daily }\end{array}$ \\
\hline \multirow[t]{2}{*}{ Laboratory } & Sinking velocities & Feb 2014 & Playa Chica & Decantation tube \\
\hline & Settler growth rates & $\begin{array}{l}\text { Dec 2009-Jan } 2010 \\
\text { Jan } 2013\end{array}$ & $\begin{array}{l}\text { Playa Chica } \\
\text { Playa Chica }\end{array}$ & $\begin{array}{l}\text { Seawater aquarium } \\
\text { Seawater aquarium }\end{array}$ \\
\hline \multirow[t]{3}{*}{ Physical drivers } & Temperature & Since Jan 2008 & Playa Chica & Tidbit $^{\circledR}$ temperature logger \\
\hline & Wind & Since Jan 2007 & ECIM & Campbell $^{\circledast}$ weather station \\
\hline & Wave & Since Jan 2007 & ECIM $^{\mathrm{a}}$ & Buoyweather consulting services \\
\hline
\end{tabular}

were 0 to 10,10 to 20 , and either 20 to 30 or 20 to $35 \mathrm{~m}$, depending on bottom depth. The small mesh size was used to ensure that we could capture both early and mature mussel larval stages. Samples were preserved in buffered formaldehyde, sorted under a dissecting microscope, identified using morphological features and published literature (Ramorino \& Campos 1979, 1983), photographed, and measured (longest dimension) under a microscope. Here, we present a summary of these results with the goal of confirming the presence and potential depth stratification of mussel larvae and planktonic postlarvae, as well as characterizing their size distribution. A complete account of results from these surveys, including physical variables, will be presented elsewhere.

\section{Plantigrade larval size in the intertidal zone}

To characterize the size distribution of settlers in natural substrates, in January 2008 we collected at Playa Chica replicated $3 \times 3 \mathrm{~cm}$ samples of the main algae reported to be mediators of intertidal settlement for these mussel species (Wieters 2005, Kelaher et al. 2007, Navarrete \& Manzur 2008), namely the coralline alga Corallina officinalis and the corticated turf alga Gelidium chilense (see Table 1). To confirm the presence of small plantigrades in established mussel beds, we also collected $5 \times 5 \mathrm{~cm}$ samples from mussel beds in the same area. We used a small sample size $(n=3)$ in mussel beds because of the generally slow recovery of these patches and because size distributions within mussel beds have already been reported for the same general area (Alvarado \& Castilla 1996, Prado \& Castilla 2006). Samples in all substrates were spread over approximately 40 to $50 \mathrm{~m}$ of rocky platforms and collected from patches located at about the same tidal level in the low shore. Collections were made with a spatula, ensuring that all algae, mussels, and their associated fauna were removed from the substratum, and placed in labeled plastic bags. Samples were cleaned and individual mussels identified and measured under a dissecting microscope. Subsamples of one-fourth of the original area of Gelidium and mussel bed samples were analyzed because of the large number of settlers. To look for evidence of benthic growth in natural substrate after initial settlement of pediveligers from the 
plankton, as prescribed by the primary-secondary settlement hypothesis, we examined settler size distributions in $5 \times 5 \mathrm{~cm}$ samples of Gelidium, Corallina, and established mussels beds collected at Playa Chica over 3 spring and summer months (December 2013, January 2014, February 2014).

To further characterize the size distribution of larvae arriving at the rocky shore, i.e. not attached to benthic substrate, we sampled intertidal water directly using a gas-powered pump equipped with a $150 \mu \mathrm{m}$ mesh and a flow meter (POWOGAZ MZ50). The mesh size ensured that we could capture pediveliger larval stages and plantigrade larvae. Samples were collected during daytime high and low tides directly from the shore of the ECIM marine reserve in spring (October) and summer (February, early March) 2009 and 2010. Between 3.3 and $10.0 \mathrm{~m}^{3}$ of water was sampled each time at 30 min intervals for roughly $3 \mathrm{~h}$. Settlers were identified and measured as indicated above.

\section{Plantigrade growth rates and sinking velocities}

Published accounts from laboratory experiments show that larvae of Perumytilus purpuratus collected in the Valparaiso area, ca. $50 \mathrm{~km}$ north of our study area, grow about $1.6 \mu \mathrm{m} \mathrm{d}^{-1}$ at 15 to $18^{\circ} \mathrm{C}$ and reach metamorphosis at a maximum size of $200 \mu \mathrm{m}$ (Ramorino \& Campos 1979). Larvae of Semimytilus algosus collected near Valdivia in southern Chile $\left(39^{\circ} 53^{\prime} \mathrm{S}\right)$ grow about $7.5 \mu \mathrm{m} \mathrm{d}^{-1}$ at $14^{\circ} \mathrm{C}$ and reach metamorphosis at a maximum size of $270 \mu \mathrm{m}$ (Garrido 1996). To obtain estimates of post-metamorphic (plantigrade) larval growth rates under the same conditions and to be able to interpret differences in larval size distributions, we collected recently settled larvae from artificial collectors deployed for $1 \mathrm{~d}$ in the mid intertidal zone of Las Cruces. Individuals of each species, between 340 and $360 \mu \mathrm{m}$ in size, were collected in early summer 2009 to 2010, carefully removed from the collectors under a microscope, and placed in $5 \mathrm{ml}$ glass vials with unfiltered seawater. Water in the vials was replaced every day, and vials were immersed in a running seawater bath at $18^{\circ} \mathrm{C}$. In summer 2013, we collected larger recruits of each species, between 665 and $680 \mu \mathrm{m}$, and cultured them in individual vials $(\mathrm{n}=30)$ immersed in running seawater at 14 to $16^{\circ} \mathrm{C}$. Individuals in vials were measured every 7 to $10 \mathrm{~d}$ under a dissecting microscope.

To determine whether mussel plantigrades were negatively buoyant, we estimated sinking velocities of individuals of varying sizes (350 to $1500 \mu \mathrm{m}$ shell length) through direct observation of individuals released in a $30 \mathrm{~cm}$ long $\times 5 \mathrm{~cm}$ diameter cylinder filled with filtered seawater. Individual mussels, sampled from artificial collectors deployed at Las Cruces, were released with micro-tweezers $3 \mathrm{~cm}$ below the water surface to avoid surface tension and reduce turbulence. The time taken for individuals to travel between 2 cylinder marks $20 \mathrm{~cm}$ apart was recorded by an observer with a stopwatch. To test for differences in sinking velocities due to behavior, 3 batches of settlers were examined in the following conditions: (1) frozen dead individuals with valves open, (2) dead individuals with valves closed (placed briefly in a $2 \%$ formaldehyde solution), and (3) live individuals.

\section{Daily settlement on the shore}

Between January and February (austral summer) 2008, the peak time for mussel recruitment (Navarrete et al. 2008), we quantified daily settlement of mussels at the Playa Chica shore in Las Cruces using artificial collectors made of plastic mesh Tuffy $^{\circledR}$. These collectors have been used extensively in recruitment studies of mussels and other invertebrate species in Chile (Narváez et al. 2006, Lagos et al. 2007, Navarrete et al. 2008, Caro et al. 2010) and elsewhere (Menge et al. 1994, Le Corre et al. 2013). Collectors can be taken back to the laboratory for identification of settlers under a dissecting scope. Their use is of critical importance here and should be highlighted. First, they ensure that individuals found in them have arrived at the collector within the time elapsed in the field, unlike samples of natural substrates found in the field. Second, settler size distributions in these collectors provide an indication of settlement and movement of individuals over daily timescales, significantly reducing the effects of growth and post-arrival mortality. Third, they significantly reduce the potential effects that the established community can have on newly arriving settlers (e.g. Navarrete \& Wieters 2000, Porri et al. 2008a), especially when they are replaced daily. All of these issues can pose significant problems when interpreting settler size distribution in natural substrates and can make it difficult to identify physical drivers of settlement (Pineda et al. 2010). Four replicate collectors, separated by 3 to $5 \mathrm{~m}$, were deployed in the mid intertidal zone and tied to a stainless screw. Once in the lab, all settled mussels were removed from the collector under a dissecting scope, identified, counted, and measured (maximum length). When more than 200 individuals of a given species were found in a 
single collector, we measured 30 randomly chosen individuals per collector. To determine whether mussel settler size varied consistently through the settlement season and to examine between-year variability in physical processes associated with settlement events, we repeated the daily settlement observations at the same site at Playa Chica over three $10 \mathrm{~d}$ periods in consecutive months, between 5 and 16 December 2013, 6 to 16 January 2014, and 5 to 16 February 2014. Modes in shell length distributions were identified with the aid of locally weighted scatterplot smoothing non-parametric fitting.

\section{Physical drivers of mussel settlement}

To explore whether physical factors modulate mussel settlement from the plankton and/or movement of plantigrade larvae once in the benthic habitat, we examined the correlation between daily settlement rates and the main physical variables that have been identified as associated with the settlement of invertebrates in previous studies in this region and elsewhere (Narváez et al. 2006). In situ sea surface temperature (SST) was measured with a Tidbit temperature logger (Onset Computer) anchored at about $1 \mathrm{~m}$ depth and a few meters from the larval collectors. Temperature was recorded at $5 \mathrm{~min}$ intervals throughout the study. Time series of wind direction and speed at $10 \mathrm{~min}$ intervals were obtained from a Campbell weather station located at the ECIM, about $1 \mathrm{~km}$ north of the main study site and at $30 \mathrm{~m}$ above MSL. Since waves can sweep and transport secondary settlers already settled in benthic habitat (Hunt \& Scheibling 1996, Porri et al. 2007) or transport invertebrate larvae across the surf zone (Shanks et al. 2010), we examined correlations between settlement and daily wave height. Wave data used in our analyses correspond to reanalysis predictions for $33.5^{\circ} \mathrm{S}$, $72.0^{\circ} \mathrm{W}$ over the $2000-2013$ period obtained by Buoyweather consulting services (see www.buoyweather.com) from the NOAA WAVEWATCH III global wave model. To determine whether these forecasts provided reasonable estimates of swell for the study area, we compared them with 4 mo of in situ data on wave height and direction recorded with a $1200 \mathrm{kHz}$ Workhorse acoustic Doppler current profiler (ADCP) equipped with a wave unit, which was anchored at $28 \mathrm{~m}$ deep in Las Cruces, about $2 \mathrm{~km}$ north of the study site, between February and June 2003. Although this period does not correspond with the dates during which our biological observations were conducted, we assumed that any offset or con- sistency found between reanalysis predictions and in situ data for 2003 would hold for our period of interest.

To determine association between settlers and physical variables, we used cross-correlation analyses. Average daily SST was calculated from the $5 \mathrm{~min}$ interval data. Daily standard deviations (SD) in SST, which correlates with high-frequency processes such as daily warming or internal wave activity (Kaplan et al. 2003, Vargas et al. 2004, Bonicelli et al. 2014), were also calculated. Wind data were decomposed in the alongshore and cross-shore components, rotating the axis according to predominant coastal orientation. In the area of Las Cruces, the coast faces southsouthwest; therefore, cross-shore winds partly capture meridional winds and can be as strong as alongshore winds (Kaplan et al. 2003, Bonicelli et al. 2014). Large-scale meridional winds drive upwelling of cold, nutrient-rich subsurface waters in the coastal zone (Wieters et al. 2003, Narváez et al. 2004, 2006, Tapia et al. 2009). To prevent spurious correlations, especially in the longer time series obtained in 2008, long-term trends in biological and physical datasets were removed by differencing (first difference) and centering the biological and physical time series before analyses. Cross-correlations for lags of 0,1 , and $2 \mathrm{~d}$ were estimated for settlement data versus mean SST, wind stress, and wave height, since these processes could produce pulses of larval or postlarval settlement after some time delay (Narváez et al. 2006).

\section{RESULTS}

\section{Larval distribution and size in the plankton}

Mature larvae of both species were found in sampling stations beyond the surf zone but within $500 \mathrm{~m}$ from shore, in waters shallower than $30 \mathrm{~m}$ (Fig. 1a,b). No indication of diel differences in larval vertical distribution were observed for either species (Fig. 1a,b). A more complete account of larval spatial distribution, variability, and relationship with hydrographic conditions will be presented elsewhere.

Larval size distribution was restricted between 120 and $190 \mu \mathrm{m}$ for Perumytilus and between 110 and $220 \mu \mathrm{m}$ for Semimytilus (Fig. 2a,b, note different $x$ axis scale), i.e. no post-metamorphic stages of these species were found in any of the plankton surveys. Mean and modal larval sizes were slightly larger in Semimytilus than in Perumytilus, in accordance with slight differences reported under laboratory condi- 


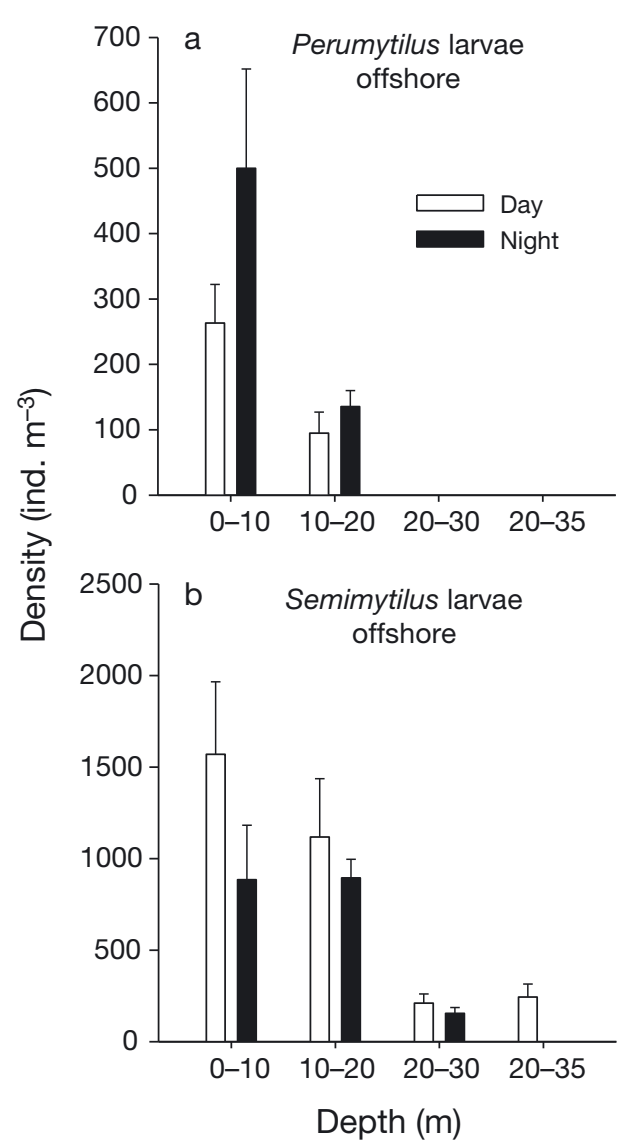

Fig. 1. Density of mussel larvae (ind. $\mathrm{m}^{-3}+\mathrm{SE}$ ) collected in stratified plankton tows conducted during days and nights off the surf zone at El Quisco for the intertidal mussels (a)

Perumytilus purpuratus and (b) Semimytilus algosus

tions, and in both cases, the modal sizes were slightly smaller than the maximum sizes at which larvae metamorphose (Ramorino \& Campos 1979, Garrido 1996). Although $9 \%$ of Perumytilus and $15 \%$ of Semimytilus larvae were larger than the maximum size at metamorphosis reported for each species in laboratory experiments, none of these individuals had a distinguishable dissoconch, which typically marks metamorphosis in mytilids. The large size of some individuals probably represents variability in size at metamorphosis of competent larvae under natural conditions.

\section{Plantigrade larval size in the intertidal zone}

Plantigrade larvae were observed in all natural substrates sampled in 2008, including algae and mussel beds (Fig. 2c-h). In all cases, the smallest plantigrade modal sizes were between 120 and $220 \mu \mathrm{m}$ larger than the modal size observed for larvae in the plankton, between 290 and $390 \mu \mathrm{m}$ larger than the mean planktonic larval size, and at least $50 \mu \mathrm{m}$ larger than the largest planktonic larva for both species (Fig. 2c-h). In the case of Perumytilus, there was weak evidence of multimodal distributions in all substrates, with mean larval size and dominant modal sizes closely similar between algal substrates Gelidium and Corallina (Fig. 2c,e) and conspecific mussel beds (Fig. 2g). Likewise, size distributions of Semimytilus plantigrades were very similar in all 3 natural substrates sampled (Fig. $2 \mathrm{~d}, \mathrm{f}, \mathrm{h}$ ). In the case of algal substrates, a much weaker size mode was observed for Semimytilus plantigrades at about $1200 \mu \mathrm{m}$ (Fig. 2d,f). The size distribution of Perumytilus plantigrades collected from intertidal water pumped directly at the rocky shore, i.e. not attached to any substrate, was remarkably similar to that observed for individuals attached to natural substrates (Fig. S2a in the Supplement). As for Semimytilus, plantigrade size distribution in the pumped water samples presented a modal size around $300 \mu \mathrm{m}$, closely similar to that observed in mussels attached to substrates, but also a larger mode at $750 \mu \mathrm{m}$ of maximum shell length (Fig. S2b in the Supplement).

Size distributions in samples collected from the 3 natural substrates in December 2013 and January and February 2014 confirmed the absence of small plantigrades $(<300 \mu \mathrm{m})$ of both species (Figs. $3 \& 4)$. Mean and modal plantigrade sizes for Perumytilus were similar among substrates and generally larger than those observed in January and February 2008 (Fig. 3). Plantigrade sizes in Semimytilus were similar among substrates and comparable to those observed in 2008 (Fig. 4). There was no clear modal displacement indicative of larval settlement and subsequent benthic growth over this 3 mo period for either species.

The size distribution of settlers found in Tuffy collectors replaced daily in 2008 closely resembled the size distribution observed in natural substrates but with stronger evidence of bimodality than any of the natural substrates (Fig. 5a,b). In the case of Perumytilus, a dominant mode was observed at $350 \mu \mathrm{m}$, and a secondary mode was observed at about $1000 \mu \mathrm{m}$ (Fig. 5a). The smallest settler was $200 \mu \mathrm{m}$ in length, and the largest was $2700 \mu \mathrm{m}$. In the case of Semimytilus, a first mode was observed at $600 \mu \mathrm{m}$, with a secondary mode at $900 \mu \mathrm{m}$ (Fig. 5b), and the smallest settler was $200 \mu \mathrm{m}$ in shell length. Because of the bimodality in size distribution, mean larval sizes are difficult to interpret. In the 2013-2014 season, modal size of Perumytilus settlers in collectors replaced daily was slightly larger (443 to $487 \mu \mathrm{m}$ 
shell length) than that observed in 2008 (Fig. 5), coincident with the pattern observed in natural substrates. Bimodality of size distributions was generally weaker than in 2008, with a feeble secondary mode at $1000 \mu \mathrm{m}$ observed only in December 2013
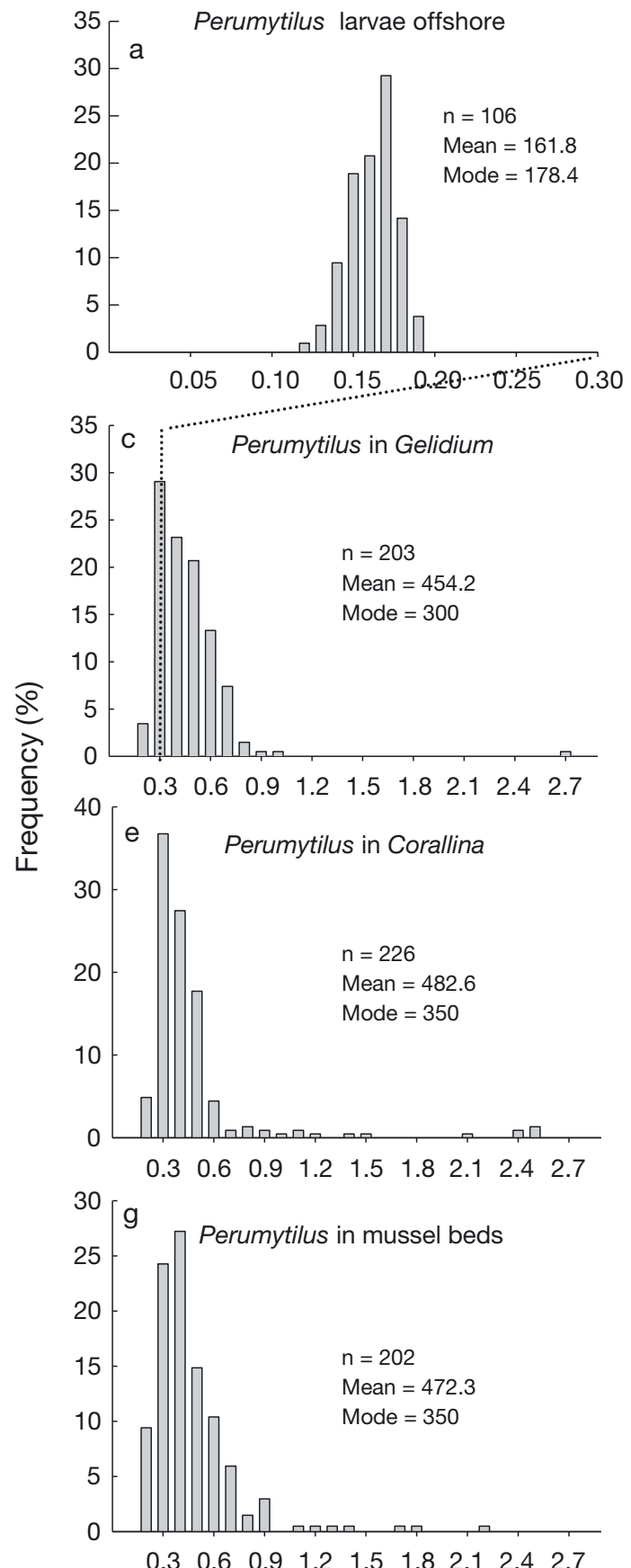

(Fig. 5c). The smallest Perumytilus plantigrade sizes fluctuated between $209 \mu \mathrm{m}$ in January and $261 \mu \mathrm{m}$ in December 2013. As for Semimytilus, modal settler sizes in December 2013 and January 2014 were slightly smaller than in summer 2008 (Fig. 5d,f), but
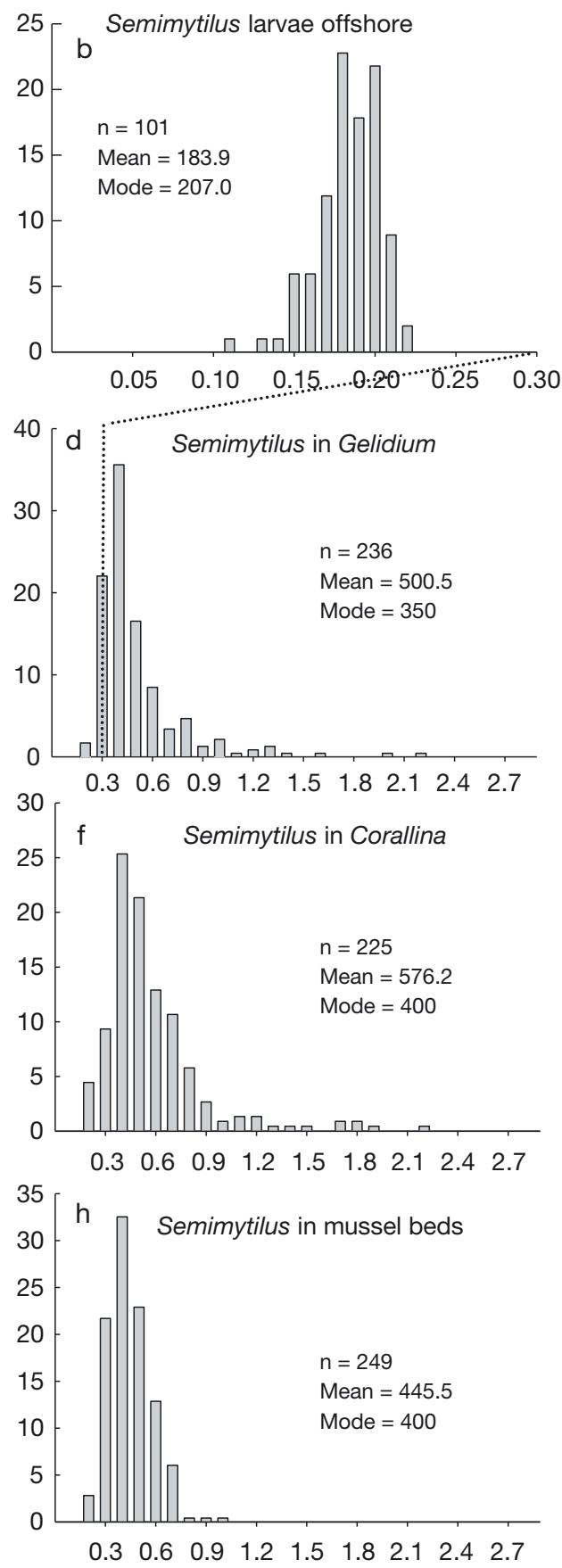

Maximum shell length $(\mathrm{mm})$

Fig. 2. (a,b) Pediveliger size (maximum shell length, $\mathrm{mm}$ ) distributions observed in water samples collected offshore of the surf zone. Settler (plantigrade) size distributions collected in summer 2008 from intertidal algal substrate represented by (c,d) Gelidium chilense and $(\mathrm{e}, \mathrm{f})$ Corallina officinalis and from $(\mathrm{g}, \mathrm{h})$ adult mussel beds for the mussels Perumytilus purpuratus (left panels) and Semimytilus algosus (right panels). Note that (a) and (b) have different $x$-axis scales than the other panels 
in February 2014, modal size was larger than that observed in 2008 (Fig. 5h). Bimodal size distribution was apparent only in February 2014. The smallest Semimytilus size recorded in this season varied between 200 and $330 \mu \mathrm{m}$. Importantly, and for both mussel species, we found no consistent displacements in modal or mean settler sizes over this 3 mo period that could indicate initial settlement at a fixed size followed by benthic growth.

\section{Plantigrade growth rates and sinking velocities}

Growth rates of small plantigrades (measured in the laboratory at 17 to $18^{\circ} \mathrm{C}$ ) were similar among species, with a tendency to grow faster during the first $15 \mathrm{~d}$ (between 6.8 and $6.9 \mu \mathrm{m} \mathrm{d}^{-1}$ ) and to grow substantially slower $\left(0.3\right.$ and $1.5 \mu \mathrm{m} \mathrm{d}^{-1}$ for Semimytilus and Perumytilus, respectively) when reaching over $450 \mu \mathrm{m}$ (Fig. 6a). Growth rates of slightly
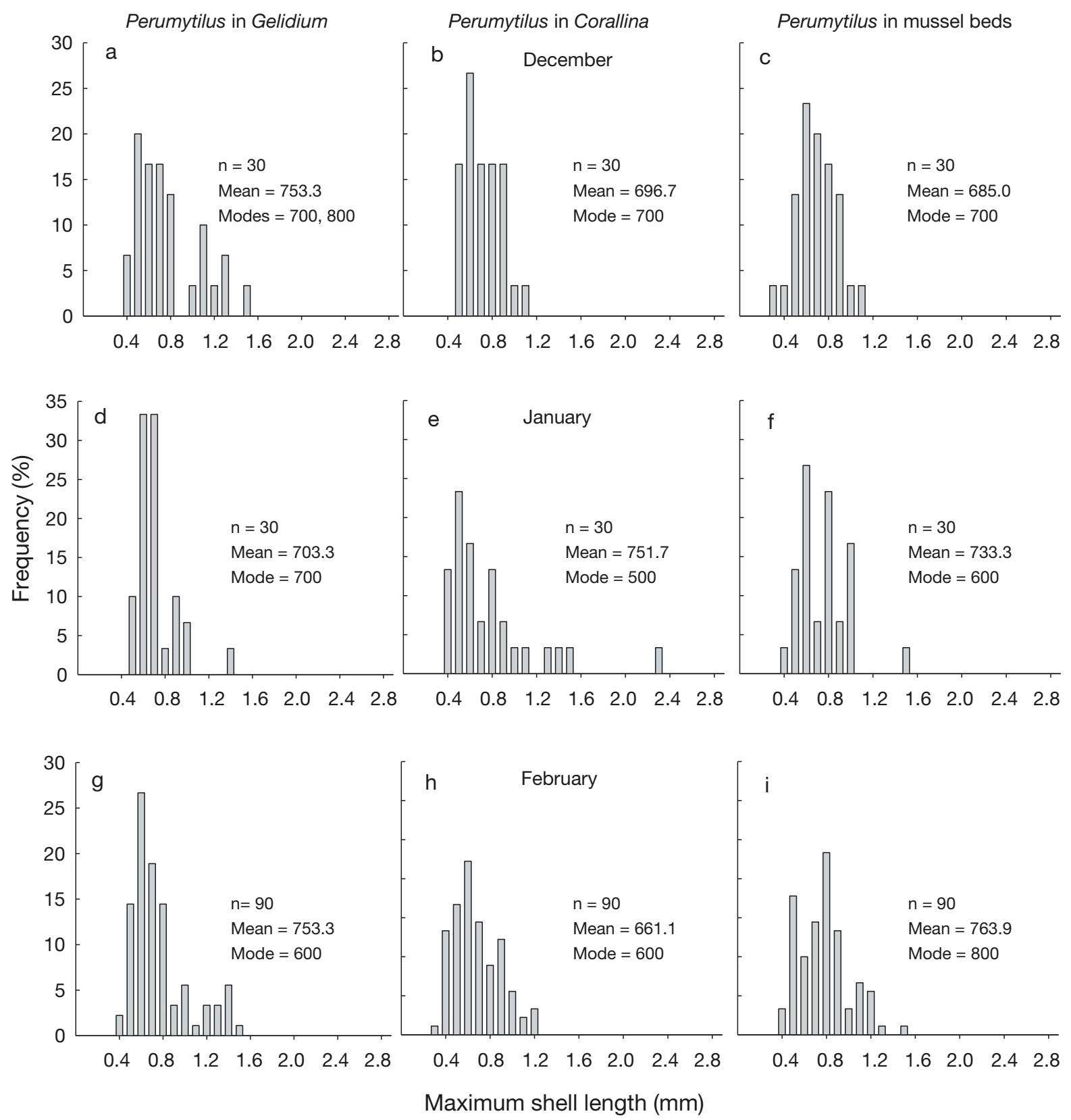

Fig. 3. Size distributions for settlers (plantigrade) of Perumytilus purpuratus observed in samples collected in summer (December 2013 and January and February 2014) from intertidal algal substrate represented by (a,d,g) Gelidium chilense and (b,e,h) Corallina officinalis and from $(\mathrm{c}, \mathrm{f}, \mathrm{i})$ adult mussel beds 
larger pediveligers were also similar between species, with increments between 2.3 and $2.9 \mu \mathrm{m} \mathrm{d}^{-1}$ for Perumytilus and Semimytilus, respectively (Fig. 6b).

Laboratory experiments to quantify buoyancy and sinking speeds of dead mussel settlers (to prevent swimming) showed strong negative buoyancy of all settler sizes of both species, regardless of whether they had open or closed valves (Fig. 6c,d). Live settlers showed a wider range of sinking velocities, but they too showed a rapid sinking behavior (Fig. 6c,d). A few individuals remained at the surface for a few seconds before sinking to the bottom.

\section{Daily settlement on the shore}

During summer 2008, daily settlement rates were between 1 and 2.5 orders of magnitude higher for Semimytilus than for Perumytilus (Fig. 7a). Daily settlement rates were tightly and positively correlated between species over time $(r=0.71, p<0.001)$. Removing settlers $>900 \mu \mathrm{m}$, which represent the secondary mode in the size distribution (Fig. 5a,b), from the analysis improved the correlation between species $(\mathrm{r}=0.84, \mathrm{p}<0.001)$. Daily arrival rates of these large settlers were not associated between spe-
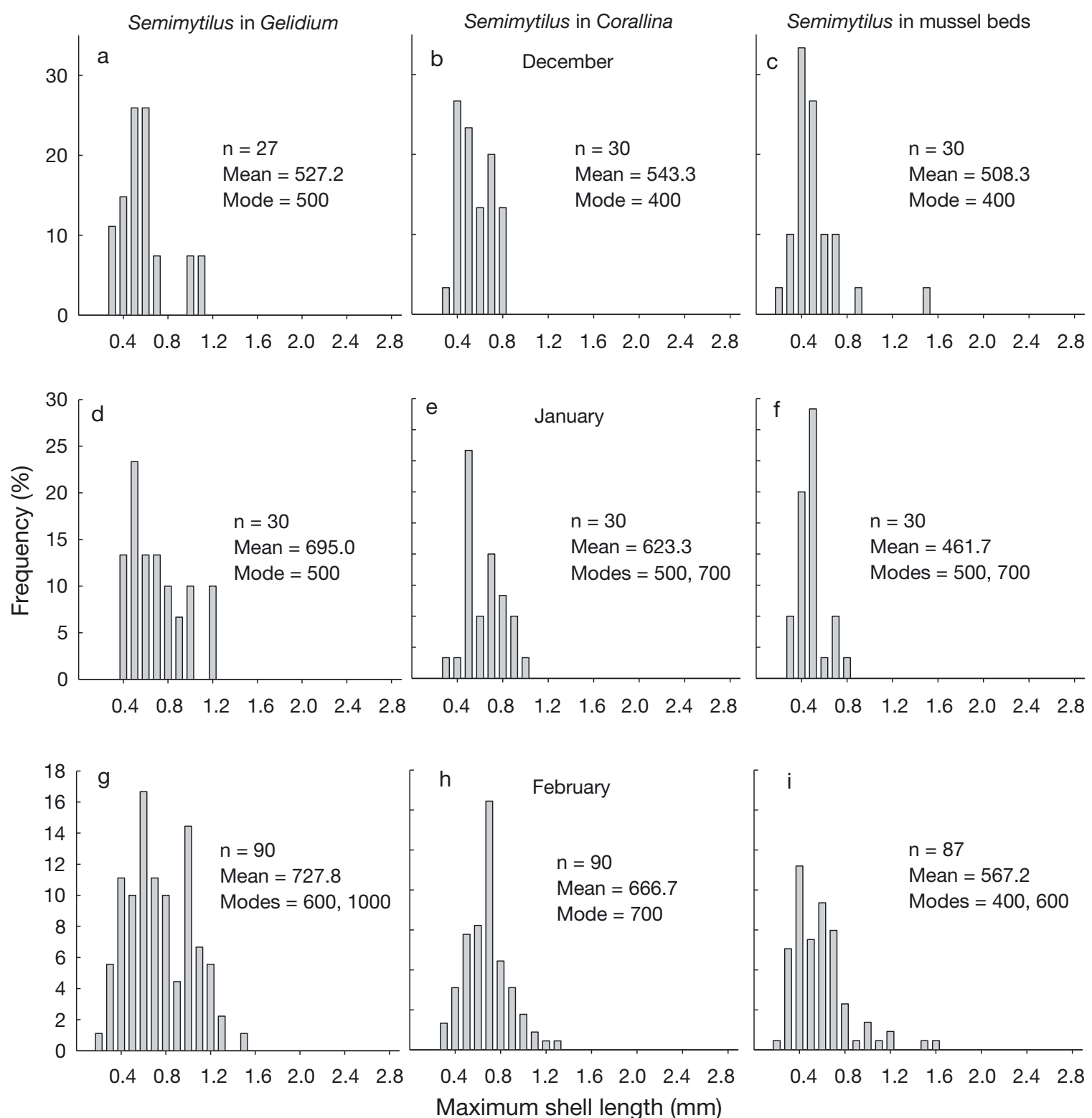

Fig. 4. Size distributions for settlers (plantigrade) of Semimytilus algosus observed in samples collected in summer (December 2013 and January and February 2014) from intertidal algal substrate represented by (a,d,g) Gelidium chilense and (b,e,h) Corallina officinalis, and from $(\mathrm{c}, \mathrm{f}, \mathrm{i})$ adult mussel beds 
cies $(r=-0.08, p=0.40)$. Consistent with our observations in 2008, daily settlement rates of Semimytilus in summer 2013 to 2014 were also much higher than and tightly correlated with those of Perumytilus ( $\mathrm{r}=$ 0.96, $\mathrm{p}<0.0001$ ) in all 3 time periods (Fig. 8a). Removing settlers $>900 \mu \mathrm{m}$ from the analysis had a
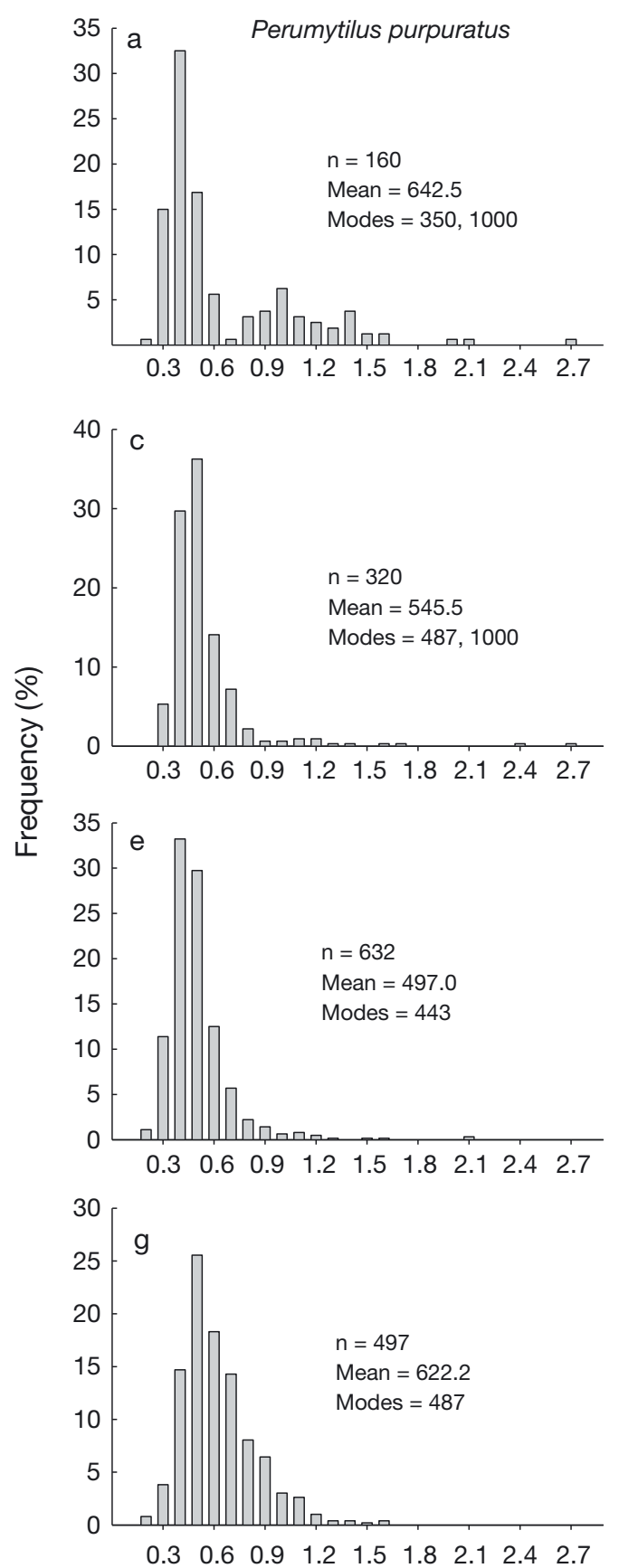

minor effect on the correlation because these larger individuals were more rare over this season. In both summer periods, the average size of settlers observed daily in the collectors was also positively and significantly correlated between species (Fig. S3 in the Supplement).
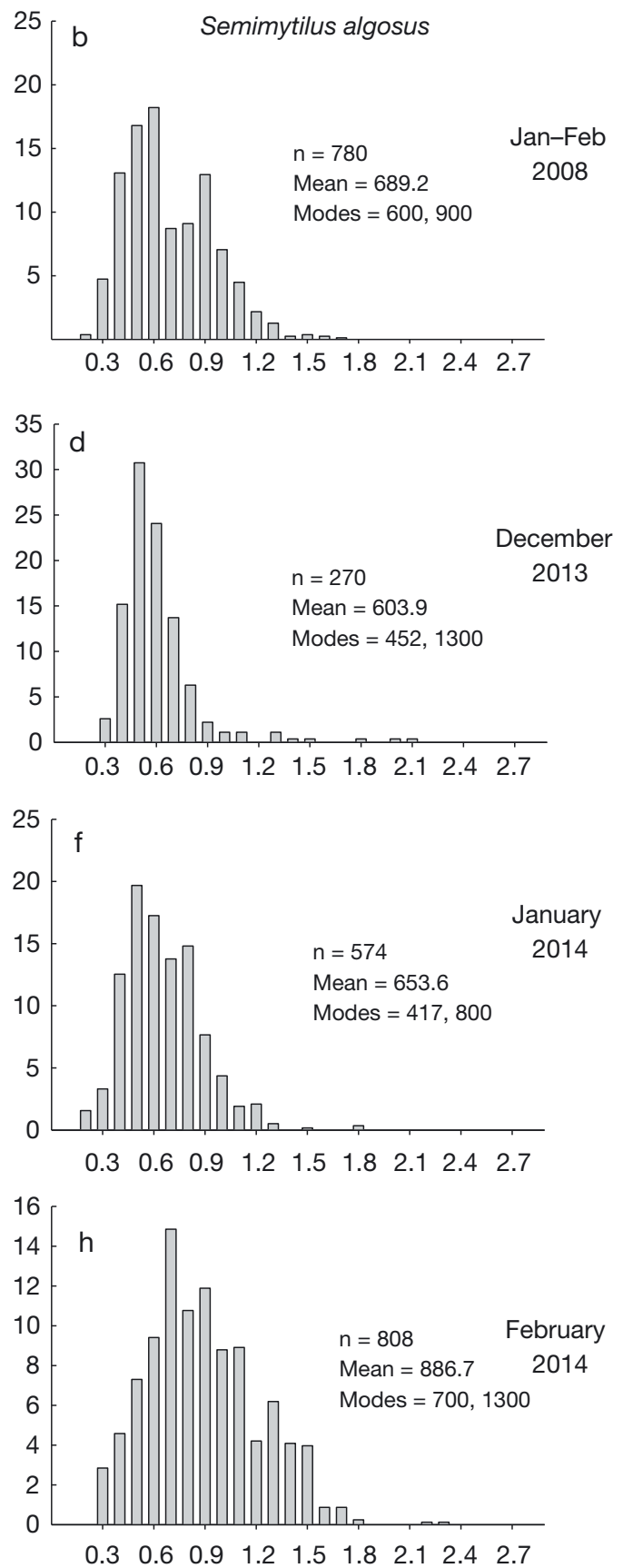

Maximum shell length $(\mathrm{mm})$

Fig. 5. Size distributions for settlers (plantigrade) of Perumytilus purpuratus (left panels) and Semimytilus algosus (right panels) observed in artificial Tuffy ${ }^{\circledR}$ collectors deployed in the intertidal zone for $1 \mathrm{~d}$ during $(\mathrm{a}, \mathrm{b})$ January to February 2008 , (c,d) December 2013, (e,f) January 2014, and $(g, h)$ February 2014 

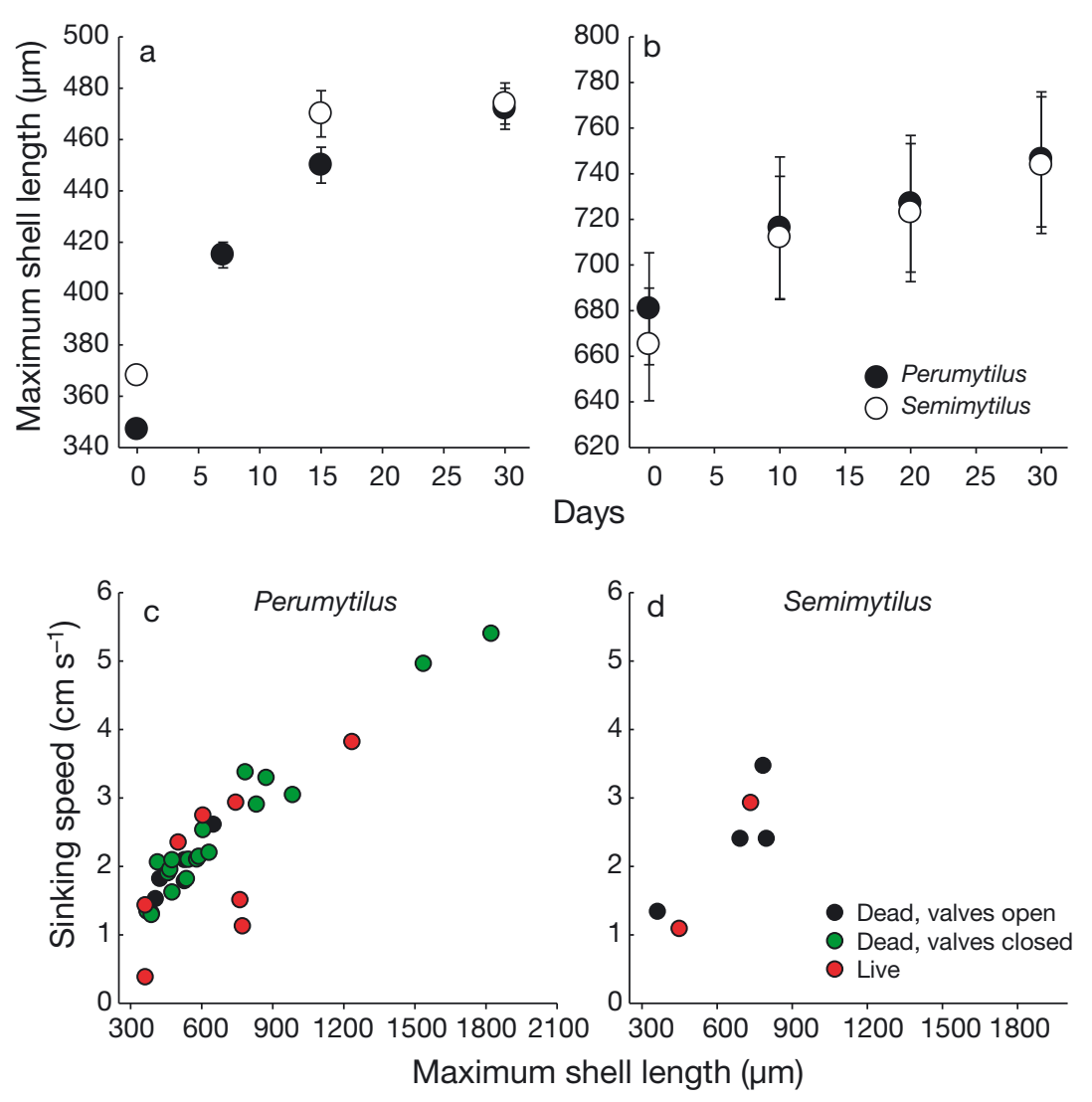

Fig. 6. Growth of pediveliger larvae cultured in the laboratory in (a) early summer 2009 to 2010 and (b) late summer 2013. Sinking velocities measured in the laboratory for dead and live plantigrades of varying shell lengths of the mussels (c) Perumytilus purpuratus and (d) Semimytilus algosus

\section{Physical drivers of mussel settlement}

In summer 2008, settlement rates of both species were generally higher between 18 January and 2 February, followed by a period of low settlement between 3 and 8 February and increased settlement again after that (Fig. 7a, note different $y$-axis scales). In summer 2013 to 2014, settlement rates of both species were generally high, with marked fluctuations in the December and January periods exhibited by sharp and coincident peaks and troughs (Fig. 8a). In early February, settlement rates of both species decreased to the lowest levels observed this summer season and slowly increased after that.

Wave height (swell) and the direction of wave propagation from the reanalysis forecast showed remarkably good agreement with wave height and direction measured in situ with an ADCP near the study site in February to June 2003 (Fig. S4 in the Supplement). Thus, model-derived wave height forecasts provided reasonable estimates of actual wave height and direction at the study site. In summer 2008, large variation in wave height was observed through the study period, with several days of large waves in mid to late January and relatively calm days the first part of February (Fig. 7b). Wave period remained relatively long during this period (Fig. 7b), indicating that wave events were primarily long-period oceanic waves rather than shortperiod waves generated by local winds. In summer 2013 to 2014, waves were slightly smaller than in 2008 and fluctuated considerably every 2 to $4 \mathrm{~d}$ (Fig. 8b). Wave period was also slightly shorter over the 2013-2014 season than in 2008 (Fig. 8b), suggesting some influence of local winds.

In summer 2008, mean daily SST increased over most of the sampling period, especially after 1 February (Fig. 7b), while the large temporal variability in daily SD of SST showed no clear trend (Fig. 7c). Cross-shore winds were weak and presented low variability during most of January, increasing only toward the end of the study period, after 7 February (Fig. 7c). Alongshore winds remained weak and stable through the study period, with 3 episodes of moderate upwelling-favorable winds (24 January, 31 January, 6 to 9 February) followed by comparatively long periods of calm (Fig. 7c). In summer 2013 to 2014, cross-shore and alongshore winds were much stronger than in summer 2008, with clear synoptic variability in all time periods (Fig. 8c). Wind intensity decreased slightly in February but still remained much higher than in 2008.

Of all physical variables analyzed in summer 2008, only wave height at lag 0 (i.e. without a delay) was significantly and positively correlated with settlement of plantigrade larvae of both mussel species (Fig. 7, Table 2). Separate analyses for settlers $>900 \mu \mathrm{m}$, which were part of a secondary mode in size distributions, showed that these large settlers were also positively correlated to wave height $(\mathrm{r}=$ 0.32 and $\mathrm{r}=0.46$ for Perumytilus and Semimytilus, respectively), but the correlation was significant only for Semimytilus. Correlations with wave height were non-significant at all other time lags tested. Across 

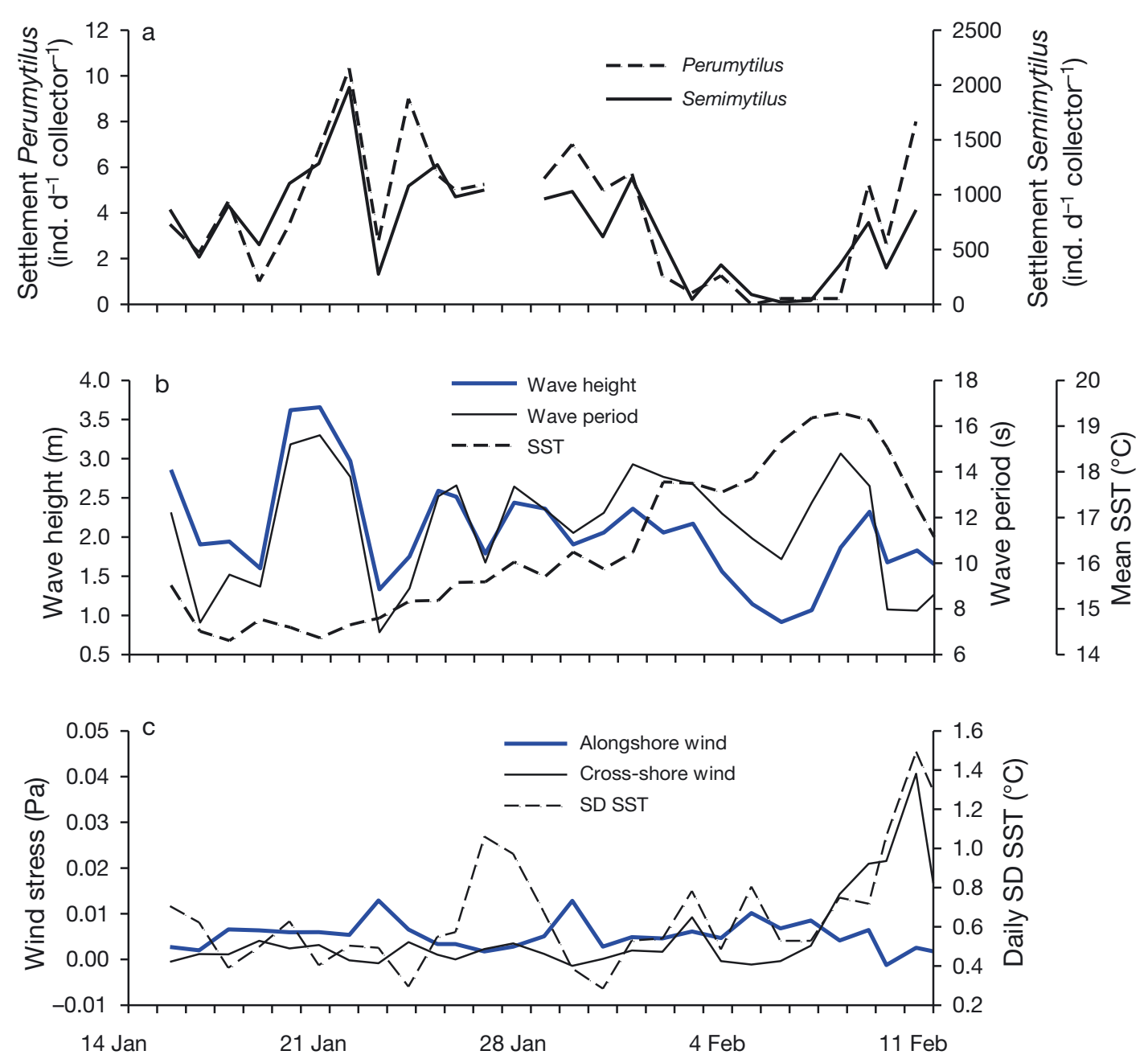

Fig. 7. (a) Time series of plantigrade mussel larvae of Perumytilus purpuratus and Semimytilus algosus settling on intertidal collectors replaced daily in summer 2008. Note different $y$-axis for the 2 species. (b) Wave height (m), wave period (s), and mean daily sea surface temperature (SST, $\left.{ }^{\circ} \mathrm{C}\right)$. (c) Alongshore and cross-shore wind stress $(\mathrm{Pa})$ and daily standard deviation

(SD) of SST

the study period and without removing longer-term trends (i.e. using raw data), wave height explained between 24 and $53 \%$ of the variance in daily settlement of Perumytilus and Semimytilus. The weak cross-shore and alongshore wind stress observed this summer, as well as daily SD of SST, was not significantly correlated with mussel settlement at any of the time lags examined (Table 2).

In summer 2013 to 2014, highly significant positive correlations at lag 0 were again observed between daily settlement rates and wave height in both mussel species and across all time periods (Fig. 8, Table 2). As in 2008, no significant correlations at any time lag were observed between mean SST, or the daily SD of SST, and mussel settlement (Table 2). In contrast to 2008 and in accordance with the stronger winds observed in summer 2013 to 2014, mussel settlement rates were significantly and negatively correlated with alongshore wind stress (Table 2), i.e. intensification of upwelling-favorable winds led to a significant decrease in mussel settlement. Crossshore winds were positively correlated to mussel settlement of both species at lag 0 and negatively correlated at lag $1 \mathrm{~d}$, although statistical significance varied between species and time lags (Table 2 ).

\section{DISCUSSION}

Our results show that neither Perumytilus purpuratus nor Semimytilus algosus possess planktonic postlarval stages. Once pediveligers reach the size of 

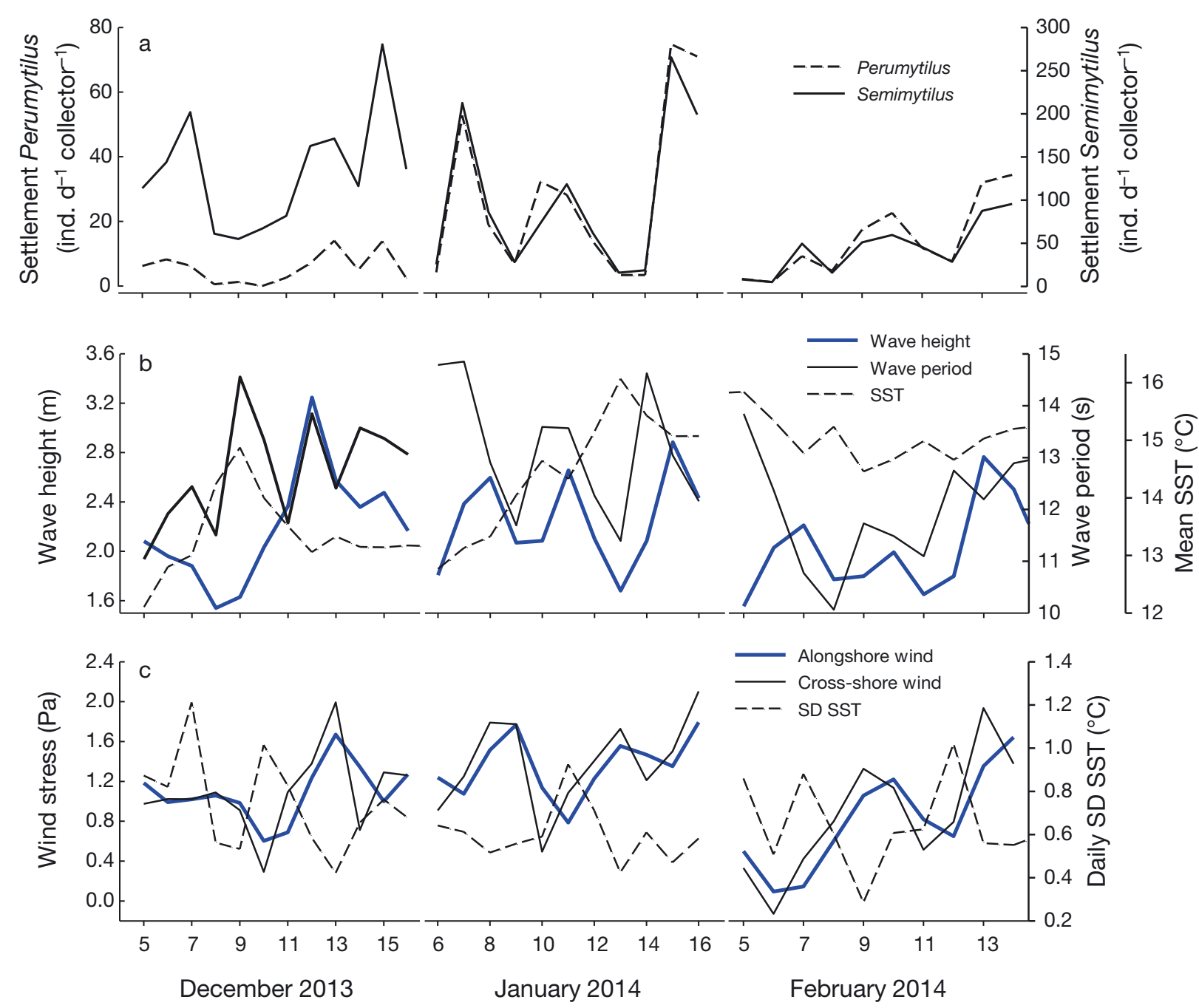

Fig. 8. (a) Time series of plantigrade mussel larvae of Perumytilus purpuratus and Semimytilus algosus settling on intertidal collectors replaced daily in December 2013 and January and February 2014. Note different $y$-axis for the 2 species. (b) Wave height $(\mathrm{m})$, wave period (s), and mean daily sea surface temperature $\left(\mathrm{SST},{ }^{\circ} \mathrm{C}\right)$. (c) Alongshore and cross-shore wind stress $(\mathrm{Pa})$ and daily standard deviation (SD) of SST

metamorphosis, they seem to disappear from the plankton in waters immediately offshore of the surf zone and reappear as plantigrade larvae in the intertidal zone about 80 to $160 \mu \mathrm{m}$ larger, which would take between 10 and $20 \mathrm{~d}$ considering the maximum growth rates measured for pediveligers in the laboratory. Less than $6 \%$ of pediveliger larvae sampled in the intertidal zone on any natural substrate or in pump water samples could be considered as recently metamorphosed. Around $10 \%$ or less, depending on the year, were late plantigrade larvae $>900 \mu \mathrm{m}$. Daily settlement of the 2 species was tightly correlated over time and strongly modulated by wave height. Increasing wave height consistently led to increased settlement rates of both species, regardless of the large discrepancy in wind conditions observed between years. During the summer characterized by calmer weather, alongshore (upwelling) or cross-shore (sea breeze) wind forcing had no effects on mussel settlement. Over the summer characterized by stronger winds, mussel settlement was inversely related to upwelling intensification and positively associated with onshore wind stress, but the positive effect of waves remained as strong as that observed on calm days. There was no evidence that mussels of these species settle from the plankton, metamorphose in benthic substrates other than mussel beds, and grow there before relocating to definitive habitat. Thus, we reject the model of primary settlement on algae and secondary settlement on mussel beds. 
Table 2. Results of cross-correlation analyses (r) between daily settlement of Perumytilus purpuratus and Semimytilus algosus and physical variables measured during the study periods in summer 2008 and 2013 to 2014. Lags between 0 and $2 \mathrm{~d}$ were calculated for the different variables. Bold indicates significant correlations at $\alpha=0.05$. Time series were differenced and centered prior to correlation analyses. SD = standard deviation; SST = sea surface temperature

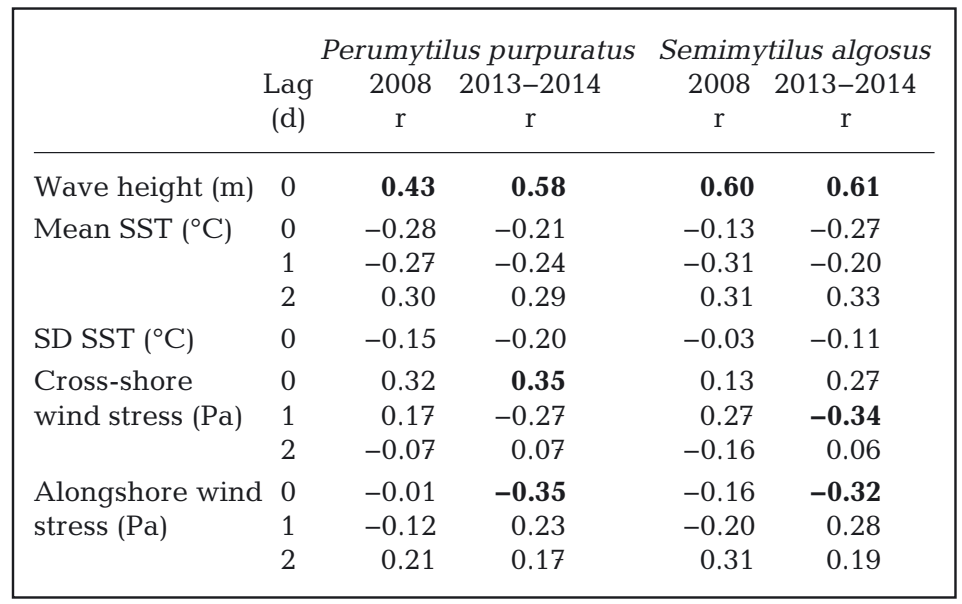

remain in the plankton, probably aided by byssus threads (e.g. Lane et al. 1982). It is unclear where larvae undergo metamorphosis before re-entering the plankton; it could be in the water column, in the intertidal zone (which is unlikely), or in the benthos beyond the surf zone. In contrast to these previous studies of mytilid species, we found no planktonic post-metamorphic stages for Perumytilus or Semimytilus, i.e. larvae found in the plankton surveys were around competence size but were premetamorphic. Since the entire water column was sampled at the plankton stations closest to shore $(<20 \mathrm{~m}$ deep), where most larvae were found, and since there was no evidence of diel vertical migration of these larval stages, we conclude that after completing development beyond the surf zone, larvae abandon the water column to metamorphose and become semi-benthic plantigrades.

Below, we discuss the biological and physical evidence for a new settlement model for these mussel species, in which competent larvae found in surface waters beyond the surf zone become semi-benthic plantigrades that 'tumble' through the surf zone until they reach the intertidal shore, a transport process that may take from a few hours to over $10 \mathrm{~d}$, depending on local bathymetry and wave regimes. Settlers arrive at all suitable habitats, including the established adult beds, at a wide range of sizes after metamorphosis, and a fraction of individuals continue relocating until reaching a 'juvenile stage', at ca. 1.5 to $2.0 \mathrm{~mm}$ in shell length.

\section{Larval competency and onshore settlement}

Several mytilid mussel species possess planktonic postlarval stages that are found in surface waters near the shore, sometimes just off the surf zone (Bayne 1964, Baker \& Mann 1997). Such is the case, for instance, for Mytilus edulis in surface waters of the Menai Strait (Bayne 1964) and M. galloprovincialis along the southern coast of South Africa (McQuaid \& Phillips 2000). In the latter case, larvae up to $800 \mu \mathrm{m}$ in size can be found in the plankton in waters $<10 \mathrm{~m}$ deep and a few hundreds of meters from the shore, beyond the surf zone (McQuaid \& Phillips 2000). Judging by their size, the majority of larvae found by McQuaid \& Phillips (2000) corresponded to post-metamorphic individuals that
If larvae metamorphose in the benthos beyond the surf zone, then settlement in the intertidal zone should involve mostly post-metamorphic plantigrades that have crossed the surf zone boundary. Our results suggest that this is exactly what happens in both species and over different seasons regardless of the intertidal substrate examined, be it algae (Gelidium, Corallina) or established mussel beds. Moreover, deployment of Tuffy collectors in shallow subtidal areas $(>5 \mathrm{~m})$ have evidenced the regular presence of recruits of both mussel species (M. Fernández \& B. Bularz unpubl. data), despite the fact that Perumytilus never forms subtidal mussel beds. This preliminary evidence demonstrates that mussel postlarvae do become semi-benthic before reaching the intertidal zone. Water samples taken directly from around intertidal rocks, as well as daily replaced artificial collectors in 2 different years, confirmed that most incoming larvae are some 80 to $150 \mu \mathrm{m}$ larger than the maximum size at metamorphosis of these species. This means that intertidal settlement in these species rarely, if ever, co-occurs with metamorphosis. Rather, intertidal settlement appears to occur toward the end of a continuous process of settlement and relocation that begins with metamorphosis in the subtidal zone, beyond the surf zone, and does not completely end after arriving at the intertidal zone. Using the upper end of our estimates of plantigrade growth rates in the laboratory $\left(6.8 \mu \mathrm{m} \mathrm{d}^{-1}\right)$, which is comparable to the lower end of growth rates measured in other species (e.g. Bayne 
1964), we estimate that reaching the intertidal zone after metamorphosis may take anywhere from $1 \mathrm{~d}$ $(<3 \%$ of the settlers that arrive at about $200 \mu \mathrm{m})$ to over $20 \mathrm{~d}$ for a large fraction of individuals. It is possible that plantigrades grow more slowly in the laboratory than in the field. In that case, the settlementrelocation process might take less time than we estimate here, but doubling growth rates would only reduce our estimates to about $10 \mathrm{~d}$ after metamorphosis for the bulk of plantigrades arriving at the shore.

Our data demonstrate that there is no 'primary settlement' on intertidal algae or other filamentous substratum followed by 'secondary settlement' into mussel beds; therefore, this settlement model should be rejected for Perumytilus and Semimytilus. Instead, our data and those available for several other mytilids (see below) are consistent with the model of continuous settlement-relocation of plantigrades as they cross through the surf zone toward the intertidal zone. We highlight 3 important differences between these 2 models to explain the mussel settlement process. First, in the primary-secondary model, planktonic larvae settle and metamorphose primarily within the intertidal zone (Bayne 1964, Seed 1969). In our alternative explanation, the majority of larvae metamorphose on offshore benthic habitats and rarely, if ever, metamorphose within the intertidal zone. This is a very important difference, with profound consequences for larval ecology and evolution. For instance, development of the capacity to detect chemical cues as a means to identify 'appropriate' intertidal habitat becomes useless in these species and the results of such studies uninterpretable. Second, in our model explanation, there is no 'primary' settlement on alternative habitat (e.g. algae) followed by subsequent relocation to mussel beds as the definitive habitat. Plantigrades simply settle, resuspend, and then tumble or drift multiple times until reaching juvenile stages. At any juvenile or later stage, individuals might become more permanently attached onto algae, mussel beds, or other substrata. In the case of Semimytilus, which also forms mussel beds in the shallow subtidal, a fraction of individuals might become permanently attached on subtidal habitat and never migrate to the intertidal zone. In the case of Perumytilus, an exclusively intertidal species, individuals will not become permanently attached until reaching the intertidal zone. The fraction of individuals relocating becomes progressively smaller as they grow. Third, in the primarysecondary model, net movement of post-metamorphic individuals is primarily alongshore, from one inter- tidal habitat to the next. In our model explanation, the most important movement of post-metamorphic individuals is cross-shore, as they are transported through the surf zone. Thus, the commonly observed behavior of plantigrades to move around in the intertidal zone (e.g. Hunt \& Scheibling 1996, Porri et al. 2008b) might be a byproduct of behavioral adaptations beneficial for crossing the surf zone.

Because logistic difficulties make it impossible to follow a large number of individuals from metamorphosis to the juvenile stage in the highly complex surf zone and intertidal environment, our understanding of the settlement process, including our own study, comes from piecing together information from different sources and stages of the processes. Therefore, the information presented in most studies varies from incomplete but compelling to outright inadequate to understand the settlement process in most mussel species. For instance, many published studies designed to evaluate the primary-secondary settlement model in Perna perna, M. edulis, M. trossulus, and M. galloprovincialis simply document length-frequency distributions of mussel recruits in different intertidal 'natural' substrates or attempt to evaluate the level of synchrony in recruitment events over variable periods of time into mussel beds and 'alternative' algal habitat (McGrath et al. 1988, Cáceres-Martínez et al. 1993, Lasiak \& Barnard 1995, Erlandsson \& McQuaid 2004, McQuaid \& Lindsay 2005, Reaugh et al. 2007). A few studies have also examined larval size in the water column and measured plantigrade growth rates (e.g. Bayne 1964). A common result of these studies is the comparatively low representation of individuals about the size of metamorphosis (250 to $300 \mu \mathrm{m}$ for most mytilid species) and the dominance of much larger plantigrades, usually $>500 \mu \mathrm{m}$, regardless of the intertidal substrate examined. Since these natural substrates are sampled weeks to even months apart (e.g. CáceresMartínez et al. 1993, Reaugh et al. 2007), allowing individuals to settle, grow, and accumulate into larger size classes, the usual explanation has been that small post-metamorphic settlers come from the plankton, and larger settlers have grown in situ or are part of a 'secondary' settling process. Synchrony in recruitment pulses between mussel beds and algal substrate is considered evidence in support of or against the primary-secondary settlement model. We argue that drawing conclusions based solely on this information constitutes a very weak inference. First, sampling natural substrates makes it impossible to determine how long the individuals have been there; therefore, one needs to assume that 'age' of 
the community does not vary significantly over space (among replicates) and between substrates. Second, there are many studies dedicated to demonstrating the sometimes complex interactions that occur between arriving settlers and the established community (Navarrete \& Wieters 2000, Porri et al. 2008a, Caro 2009), which can greatly distort sizes, rates, and timing of arrival of individuals between substrates just centimeters to meters apart. Third, evaluating synchrony in recruitment among substrates at periods of weeks to months apart to infer which is the 'primary' settlement habitat is a rather futile exercise. One must assume that larvae arrive at a precise fixed size to the intertidal zone, that mortality rates and individual growth rates in the elapsed time are density independent and the same across all substrates, and that emigration after settlement does not erase the signal of initial settlement weeks to months earlier. If individuals arrive at the intertidal zone at a wide range of sizes, as we demonstrate here for the Chilean intertidal mussels, one cannot infer the time of first settlement and identify settlement pulses based on biweekly or weekly observations, even when using artificial substrates (Le Corre et al. 2013). Only a handful of studies have conducted high-frequency observations on mussel settlement in natural (algae, mussel beds) or artificial collectors, and they have generally documented that a very large fraction of settlers arriving at the intertidal zone, on a daily or semi-daily basis, are large post-metamorphic individuals (Bayne 1964, Hunt \& Scheibling 1998, McQuaid \& Lindsay 2005, Porri et al. 2008b, this study). We argue that this may not be because primary settlement occurs in some other intertidal substrate but because metamorphosis occurs offshore, and it takes time for post-metamorphic larvae to be transported onshore.

There is no doubt that intertidal recruitment of many mussel species, including $M$. edulis, $M$. trossulus, Perna perna, Perumytilus purpuratus, and S. algosus, is facilitated by the filamentous substrate provided by different algal species (Seed 1969, Moreno 1995, Erlandsson 2004, Erlandsson \& McQuaid 2004, Navarrete et al. 2005, Wieters 2005). However, there has never been a direct test of the idea put forward by Bayne (1964) and Seed (1969) as the driving force behind the primary-secondary model, i.e. that there are selective pressures to settle first in these substrates and move to mussel beds only after a few months of benthic life. This adaptive explanation implies that mortality of early settlers in mussel beds is higher than in algae and that conditions for larger plantigrades are indeed more favorable in the mussel bed than in filamentous algae, to the extent that it pays off to migrate from one habitat to the other despite the associated risks of mortality during emigration. No studies have assessed the survival of recently metamorphosed versus late plantigrades in the different types of substrates. While cannibalism by established mussels on settling postlarvae can be important in some species (Porri et al. 2008a), predation on mussel recruits in intertidal algal turfs can be extremely high (Navarrete \& Castilla 1988, Navarrete et al. 2005, Navarrete \& Manzur 2008, Wieters et al. 2009). Moreover, the few experiments that have evaluated settlement preferences of mussel larvae, such as $M$. californianus and $M$. trossulus, do show that they settle into conspecific or heterospecific mussel beds (Petersen 1984), although algal chemical cues have been shown to enhance settlement in Perna canaliculus (Alfaro et al. 2006). Finally, in the case of $M$. trossulus, Choromytilus chorus, Perumytilus purpuratus, and $S$. algosus, individuals can overgrow and completely outcompete the filamentous algae in which they settle (Moreno 1995, Navarrete 1996, Navarrete et al. 2005, Wieters 2005). Thus, there is no need to move to previously established mussel beds to reach juvenile and adult stages.

Despite large differences in settlement rates between species, daily settlement of Perumytilus and Semimytilus were tightly and positively correlated over time over 2 different summers with contrasting environmental conditions (see below). Spatial correlation between species, among the collectors spaced just a few meters apart, was also positive and significant (average Pearson $r=0.61$ ). These patterns were not influenced by the large plantigrades $(>900 \mu \mathrm{m})$ that settled in comparatively large numbers in summer 2008 and formed a secondary mode in the size distributions (see Fig. 5a,b). The tight temporal correlation on different summers is therefore not solely the result of waves sweeping large individuals over the rocks, as observed for instance in Mytilus species in Nova Scotia (Hunt \& Scheibling 1996), but strongly suggests the influence of physical processes with day to day variability and which are spatially coherent at least over scales of the tens of meters over which the collectors were spread.

\section{Physical transport through the surf zone}

The idea that breaking waves in the surf zone can be a barrier to or facilitate larval recruitment of invertebrates in the intertidal zone has been suggested by several authors (McQuaid \& Lindsay 2005, Steffani \& 
Branch 2005, Rilov et al. 2008, Pfaff et al. 2011), and recently Shanks et al. (2010) suggested a more mechanistic basis for such effects. In this study, we see only younger larvae and a marked absence of larger post-metamorphic larvae in offshore plankton. This is interpreted as a movement into benthic environments as larval body density increases and exceeds water density post-metamorphosis - mussel larvae that are heavier than water can fall through the water column, even in the presence of high turbulence (Fuchs \& DiBacco 2011). Our short experiments with post-metamorphic larvae showed that individuals with valves closed, or dead ones with valves open, sink rapidly in the water column. In fact, their fall velocities are not too different from those of sand grains of similar diameter (Dietrich 1982), showing that they could easily reach the bottom after metamorphosis and be transported onshore like sand. Interestingly, in our experiments, active post-metamorphic settlers sank at similar rates as dead individuals, but more experiments must be performed over a range of turbulence scenarios to elucidate the possible role of swimming behavior in shallow subtidal waters. We discard alternative explanations for the disappearance of larger larvae from the plankton as very unlikely. Larger larvae could have become neustonic, but the neuston was sampled and larger size classes were absent. Larger larvae could have moved onshore rapidly, but no larvae of appropriate size were found on intertidal substrates. Further, the correlation of settlement on intertidal habitats with large, long-period waves corroborates the presence of heavier than water larvae on the bed. During wave events, sedimentary particles will be moved onshore if they have a fall velocity that matches wave period and height (such that the particle is likely to be resuspended for onshore flow but returns to the bed prior to the subsequent offshore flow several seconds later). As a larva grows in size, its fall velocity increases, so that while it may sink slowly at metamorphosis, this will change as it matures, and any concomitant increase in density will further increase fall velocity. Short-period wind waves are less effective in driving onshore transport, allowing less time for resuspended particles to fall back to the bed before the flow reverses, and they only produce near-bottom currents in shallower water (typically $<5 \mathrm{~m}$ ). On the other hand, long-period waves may drive onshore transport in depths of $20 \mathrm{~m}$ or even more (Dean \& Dalrymple 2002, George \& Hill 2008). The time elapsed between metamorphosis offshore that results in disappearance of larvae from the plankton and the subsequent reappearance of 3 to $20 \mathrm{~d}$ post-metamor- phic larvae at the shoreline can be explained by a combination of time required for larvae to develop adequate fall velocity and time spent in offshore benthic environments awaiting a suitable wave event. When fall velocity and wave height/period match, sedimentary particles may be moved onshore rapidly (order of a day). It is expected that this wave-driven near-bed transport may be effective out to depths of ca. $30 \mathrm{~m}$ during a large, long-period swell. The importance of near-bed transport for bivalve larvae has previously been discussed by Emerson \& Grant (1991). While onshore larval transport due to waves may be accompanied by onshore transport of inorganic sediment with the same fall velocity, typically sediment in this region is dominated by coarser sand particles with faster fall velocities, as finer particles are removed during more intense winter storms. Nevertheless, the spatial patchiness of sand accumulated on the shoreline is a visual example of the spatial patchiness that one may expect for the wave-driven delivery of larvae to shoreline environments.

The strong correlation between waves and the appearance of post-metamorphic larvae at the shoreline, despite large differences in wind forcing between years, is a key finding of this work and provides evidence for an offshore benthic phase in the mussel life cycle immediately following planktonic metamorphosis. In years of unusually calm days for this region (Narváez et al. 2004), like those we observed in summer 2008, winds did not have any measurable effect on daily settlement, and only wave height appears to modulate daily settlement on the shore. In years of moderate to strong winds, like the 2013-2014 summer, a similarly tight relationship between waves and settlement was observed, but synoptic variability in upwelling-favorable and onshore winds also had significantly negative and positive effects on mussel settlement, respectively. We interpret these relationships as the result of wind-forced transport of pre-metamorphic competent larvae while in the upper water column, with onshore winddriven transport thus delivering larvae to nearshore waters shallow enough that benthic, post-metamorphic larvae can be transported onshore during wave events (and offshore wind-driven transport would reduce the number of larvae that will fall out in shallow wave-influenced benthic environments). The importance of multiple phases in the transport of planktonic larvae, and thus complex settlement time series, has also been recently reported by Pfaff et al. (in press). On the shores of the Gulf of St. Lawrence, Canada, Le Corre et al. (2013) found a strong positive correlation between weekly measured Mytilus spp. 
recruitment and mean wind speed during that period of time, which they interpret as a result of a positive association between winds and waves, which could move large settlers around. But such weekly scale correlations should be taken with much care, as they could reflect many other interacting processes. Thus, interactions between transport processes need further attention, specifically the importance of mean onshore flow below the Ekman layer associated with wind-driven upwelling (cf. Morgan et al. 2009) and onshore wind stress (Tapia et al. 2004, Bonicelli et al. 2014) and the interaction between waves, currents, and topography.

Although one may invoke alternative explanations for the association between waves and shoreline settlement, these alternatives do not seem to explain our observations. First, one may suggest that larger waves and associated rip current circulation simply increase the net flux of larvae to the shoreline, with competent larvae actively settling in shoreline environments. However, one would then expect to see at least some smaller larvae at the shoreline, both those caught in Tuffy collectors and algal beds as well as those in water samples. This is not the case. Second, one may suggest that larger waves are critical to explain settlement on substrates above MSL by increasing immersion time for those environments. While this may enhance the benefit of large, longperiod waves, again it would not explain the time dependence in pumped subtidal water samples along the shoreline.

In summary, our study allows us to propose a model of mussel settlement onshore that differs in many ways from previous explanations proposed for these and other taxa. We do not claim that the model applies universally to all mytilid mussel species but that it may explain observed settlement patterns of many species on different shores of the world and should be considered and evaluated in those systems. We also do not claim that this is the only onshore settlement mechanism for the 2 Chilean mussel species, but we show that it is an important and potentially widespread mechanism under a wide range of geomorphological and hydrodynamic conditions. In any case, the model highlights the urgent need to improve knowledge of surf zone dynamics in rocky shores (Rilov et al. 2008, Shanks et al. 2010, Pfaff et al. in press) if we are to improve understanding of the mechanisms driving the supply of individuals to intertidal populations. Specifically, it questions some previous explanations and inferences based on inadequate empirical data and also raises some new hypotheses and makes several assump- tions that we trust will stimulate research on oceanography and larval ecology in upwelling, waveexposed environments like those off Chile and in other coastal ecosystems.

Acknowledgements. We are indebted to several friends and students that assisted us in the field or during the analysis of samples in the laboratory. A preliminary study by Juliette Gaillard set the stage for this work. Comments by reviewers on an earlier version encouraged us to expand the databases and better focus this study. Funding for this project and for international collaborations was provided by Fondecyt grant \#1070035 and, especially, by Fondecyt grant \#1120158 to S.A.N. and Fondecyt grant \#1120896 to F.J.T., which allowed us to obtain the last set of observations and supported this international collaboration. Additional funding for maintenance of oceanographic and meteorological instruments was provided by the Center for Marine Conservation, Nucleo Milenio Initiative P10-033F.

\section{LITERATURE CITED}

Alfaro AC, Copp BR, Appleton DR, Kelly S, Jeffs AG (2006) Chemical cues promote settlement in larvae of the green-lipped mussel, Perna canaliculus. Aquacult Int 14: 405-412

Alvarado JL, Castilla JC (1996) Tridimensional matrices of Perumytilus purpuratus on intertidal platforms with varying wave forces in central Chile. Mar Ecol Prog Ser 133:135-141

Baker P, Mann R (1997) The postlarval phase of bivalve mollusks: a review of functional ecology and new records of postlarval drifting of Chesapeake Bay bivalves. Bull Mar Sci 61:409-430

> Bayne BL (1964) Primary and secondary settlement in Mytilus edulis L. (Mollusca). J Anim Ecol 33:513-523

> Bonicelli J, Moffat C, Navarrete SA, Tapia FJ (2014) Spatial differences in thermal structure and variability within a small bay: interplay of diurnal winds and tides. Cont Shelf Res 88:72-80

Bownes SJ, McQuaid CD (2006) Will the invasive mussel Mytilus galloprovincialis Lamarck replace the indigenous Perna perna L. on the south coast of South Africa? J Exp Mar Biol Ecol 338:140-151

> Bownes SJ, McQuaid CD (2009) Mechanisms of habitat segregation between an invasive and an indigenous mussel: settlement, post-settlement mortality and recruitment. Mar Biol 156:991-1006

Broitman BR, Navarrete SA, Smith F, Gaines SD (2001) Geographic variation of southeastern Pacific intertidal communities. Mar Ecol Prog Ser 224:21-34

Buchanan S, Babcock R (1997) Primary and secondary settlement by the greenshell mussel Perna canaliculus. J Shellfish Res 16:71-76

Cáceres-Martínez J, Robledo JAF, Figueras A (1993) Settlement of mussels Mytilus galloprovincialis on an exposed rocky shore in Ria de Vigo, NW Spain. Mar Ecol Prog Ser 93:195-198

Caro A (2009) Efecto de la variabilidad en el reclutamiento sobre la estructura comunitaria y la competencia por espacio en el sistema intermareal de Chile central. PhD, Pontificia Universidad Católica de Chile, Santiago 
Caro AU, Navarrete SA, Castilla JC (2010) Ecological convergence in a rocky intertidal shore metacommunity despite high spatial variability in recruitment regimes. Proc Natl Acad Sci USA 107:18528-18532

Dean R, Dalrymple R (2002) Coastal processes. Cambridge University Press, Cambridge

$>$ Dietrich W (1982) Settling velocities of natural particles. Water Resour Res 18:1615-1626

Emerson C, Grant J (1991) The control of soft-shell clam (Mya arenaria) recruitment on intertidal sandflats by bedload sediment transport. Limnol Oceanogr 36:1288-1300

Erlandsson J, McQuaid CD (2004) Spatial structure of recruitment in the mussel Perna perna at local scales: effects of adults, algae and recruit size. Mar Ecol Prog Ser 267:173-185

Erlandsson J, Porri F, McQuaid CD (2008) Ontogenetic changes in small-scale movement by recruits of an exploited mussel: implications for the fate of larvae settling on algae. Mar Biol 153:365-373

> Fernández M, Jaramillo E, Marquet PA, Moreno CA and others (2000) Diversity, ecology and biogeography of nearshore benthic ecosystems: an overview and needs for conservation. Rev Chil Hist Nat 73:629-662

Fuchs HL, DiBacco C (2011) Mussel larval responses to turbulence are unaltered by larval age or light conditions. Limnol Oceanogr Fluids Environ 1:120-134

Garrido OA (1996) Biología comparada de la reproducción en moluscos bivalvos Mytilidae. PhD thesis, Universidad Austral de Chile, Valdivia

George DA, Hill PS (2008) Wave climate, sediment supply and the depth of the sand-mud transition: a global survey. Mar Geol 254:121-128

> Hunt HL, Scheibling RE (1995) Structure and dynamics of mussel patches in tidepools on a rocky shore in Nova Scotia, Canada. Mar Ecol Prog Ser 124:105-115

> Hunt HL, Scheibling RE (1996) Physical and biological factors influencing mussel (Mytilus trossulus, M. edulis) settlement on a wave-exposed rocky shore. Mar Ecol Prog Ser 142:135-145

> Hunt HL, Scheibling RE (1998) Spatial and temporal variability of patterns of colonization by mussels (Mytilus trossulus, $M$. edulis) on a wave-exposed rocky shore. Mar Ecol Prog Ser 167:155-169

Kaplan DM, Largier JL, Navarrete SA, Guiñez R, Castilla JC (2003) Large diurnal temperature fluctuations in the nearshore water column. Estuar Coast Shelf Sci 57: 385-398

> Kelaher BP, Castilla JC, Prado L (2007) Is there redundancy in bioengineering for molluscan assemblages on the rocky shores of central Chile? Rev Chil Hist Nat 80: 173-186

Keough MJ, Downes BJ (1982) Recruitment of marine invertebrates: the role of active larval choices and early mortality. Oecologia 54:348-352

Lagos NA, Tapia FJ, Navarrete SA, Castilla JC (2007) Spatial synchrony in the recruitment of intertidal invertebrates along the coast of central Chile. Mar Ecol Prog Ser 350:29-39

> Lane DJW, Nott JA, Crisp DJ (1982) Enlarged stem glands in the foot of the post-larval mussel, Mytilus edulis: adaptations for bysso-pelagic migrations. J Mar Biol Ass U K 62: 809-818

> Largier JL (2003) Considerations in estimating larval dispersal distances from oceanographic data. Ecol Appl 13: 71-89
Lasiak TA, Barnard TCE (1995) Recruitment of the brown mussel Perna perna onto natural substrata: a refutation of the primary/secondary settlement hypothesis. Mar Ecol Prog Ser 120:147-153

> Le Corre N, Martel AL, Guichard F, Johnson LE (2013) Variation in recruitment: differentiating the roles of primary and secondary settlement of blue mussels Mytilus spp. Mar Ecol Prog Ser 481:133-146

McGrath D, King PA, Gosling EM (1988) Evidence for the direct settlement of Mytilus edulis larvae on adult mussel beds. Mar Ecol Prog Ser 47:103-106

> McQuaid CD, Lindsay JR (2005) Interacting effects of wave exposure, tidal height and substratum on spatial variation in densities of mussel Perna perna plantigrades. Mar Ecol Prog Ser 301:173-184

McQuaid CD, Phillips TE (2000) Limited wind-driven dispersal of intertidal larvae: in situ evidence from the plankton and the spread of the invasive species Mytilus galloprovincialis in South Africa. Mar Ecol Prog Ser 201: 211-220

Menge BA, Berlow EL, Blanchette C, Navarrete SA, Yamada SB (1994) The keystone species concept: variation in interaction strength in a rocky intertidal habitat. Ecol Monogr 64:249-286

Mizrahi D, Navarrete SA, Flores AAV (2014) Groups travel further: pelagic metamorphosis and polyp clustering allow higher dispersal potential in sun coral propagules. Coral Reefs 33:443-448

Moreno CA (1995) Macroalagae as a refuge from predation for recruits of the mussel Choromytilus chorus (Molina 1782) in southern Chile. J Exp Mar Biol Ecol 191:181-193

> Morgan SG, Fisher JL, Mace AJ (2009) Larval recruitment in a region of strong, persistent upwelling and recruitment limitation. Mar Ecol Prog Ser 394:79-99

> Narváez DA, Poulin E, Leiva G, Hernández E, Castilla JC, Navarrete SA (2004) Seasonal and spatial variation of nearshore hydrographic conditions in central Chile. Cont Shelf Res 24:279-292

- Narváez DA, Navarrete SA, Largier J, Vargas CA (2006) Onshore advection of warm water, larval invertebrate settlement, and relaxation of upwelling off central Chile. Mar Ecol Prog Ser 309:159-173

> Navarrete SA (1996) Variable predation: effects of whelks on a mid-intertidal successional community. Ecol Monogr 66:301-322

> Navarrete SA, Castilla JC (1988) Foraging activities of Chilean intertidal crabs Acanthocyclus gayi MilneEdwards et Lucas and A. hassleri Rathbun. J Exp Mar Biol Ecol 118:115-136

> Navarrete SA, Manzur T (2008) Individual- and populationlevel responses of a keystone predator to geographic variation in prey. Ecology 89:2005-2018

> Navarrete SA, Wieters EA (2000) Variation in barnacle recruitment over small scales: larval predation by adults and maintenance of community pattern. J Exp Mar Biol Ecol 253:131-148

Navarrete SA, Broitman B, Wieters EA, Finke GR, Venegas RM, Sotomayor A (2002) Recruitment of intertidal invertebrates in the southeast Pacific: inter-annual variability and the 1997-1998 El Niño. Limnol Oceanogr 47:791-802

Navarrete SA, Wieters E, Broitman B, Castilla JC (2005) Scales of benthic-pelagic coupling and the intensity of species interactions: from recruitment limitation to topdown control. Proc Natl Acad Sci USA 102:18046-18051 
Navarrete SA, Broitman BR, Menge BA (2008) Interhemispheric comparison of recruitment to rocky intertidal communities: pattern persistence and scales of variation. Ecology 89:1308-1322

> Navarrete SA, Gelcich S, Castilla JC (2010) Long-term monitoring of coastal ecosystems at Las Cruces, Chile: defining baselines to build ecological literacy in a world of change. Rev Chil Hist Nat 83:143-157

Paine RT, Castilla JC, Cancino J (1985) Perturbation and recovery patterns of starfish-dominated intertidal assemblages in Chile, New Zealand, and Washington state. Am Nat 125:679-691

- Petersen JH (1984) Larval settlement behavior in competing species: Mytilus californianus Conrad and M. edulis L. J Exp Mar Biol Ecol 82:147-159

Pfaff MC, Branch GM, Wieters EA, Branch RA, Broitman BR (2011) Upwelling intensity and wave exposure determine recruitment of intertidal mussels and barnacles in the southern Benguela upwelling region. Mar Ecol Prog Ser 425:141-152

Pfaff MC, Branch GM, Fisher JL, Hoffmann V, Ellis AG, Largier JL (in press) Delivery of marine larvae to shore requires multiple sequential transport mechanisms. Ecology

Pineda J, Porri F, Starczak V, Blythe J (2010) Causes of decoupling between larval supply and settlement and consequences for understanding recruitment and population connectivity. J Exp Mar Biol Ecol 392:9-21

Porri F, McQuaid CD, Radloff S (2006) Spatio-temporal variability of larval abundance and settlement of Perna perna: differential delivery of mussels. Mar Ecol Prog Ser 315:141-150

> Porri F, Zardi GI, McQuaid CD, Radloff S (2007) Tidal height, rather than habitat selection for conspecifics, controls settlement in mussels. Mar Biol 152:631-637

Porri F, Jordaan T, McQuaid CD (2008a) Does cannibalism of larvae by adults affect settlement and connectivity of mussel populations? Estuar Coast Shelf Sci 79: $687-693$

Porri F, McQuaid CD, Lawrie SM, Antrobus SJ (2008b) Finescale spatial and temporal variation in settlement of the intertidal mussel Perna perna indicates differential hydrodynamic delivery of larvae to the shore. J Exp Mar Biol Ecol 367:213-218

Prado L, Castilla JC (2006) The bioengineer Perumytilus purpuratus (Mollusca: Bivalvia) in central Chile: biodiversity, habitat structural complexity and environmental heterogeneity. J Mar Biol Ass UK 86:417-421

Queiroga H, Cruz T, dos Santos A, Dubert J and others (2007) Oceanographic and behavioural processes affecting invertebrate larval dispersal and supply in the western Iberia upwelling ecosystem. Prog Oceanogr 74:174-191

Ramorino L, Campos B (1979) Desarrollo larval y postlarval de Perumytilus purpuratus (Lamarck, 1819). Bivalvia: Mytilidae. An Mus Hist Nat Valpso 12:207-218

Ramorino L, Campos B (1983) Larvas y postlarvas de Mytili-

Editorial responsibility: Richard Osman,

Edgewater, Maryland, USA dae de Chile (Mollusca: Bivalvia). Rev Biol Mar 19: 143-192

> Reaugh KE, Harris JM, Branch GM (2007) Further refutation of the primary-secondary settlement hypothesis for the brown mussel Perna perna. Afr J Mar Sci 29:545-549

Rilov G, Dudas S, Menge BA, Grantham BA, Lubchenco J, Schiel DR (2008) The surf zone: a semi-permeable barrier to onshore recruitment of invertebrate larvae? J Exp Mar Biol Ecol 361:59-74

> Seed R (1969) The ecology of Mytilus edulis L. (Lamellibranchiata) on exposed rocky shores. Oecologia 3: 277-316

Shanks AL (1995) Mechanisms of cross-shelf dispersal of larval invertebrates and fish. In: McEdward L (ed) Ecology of marine invertebrate larvae. CRC Press, Boca Raton, FL, p 323-367

Shanks AL, Shearman RK (2011) Thread-drifting juvenile Mytilus spp. in continental shelf waters off Coos Bay, Oregon, USA. Mar Ecol Prog Ser 427:105-115

Shanks AL, Morgan SG, MacMahan J, Reniers A (2010) Surf zone physical and morphological regime as determinants of temporal and spatial variation in larval recruitment. J Exp Mar Biol Ecol 392:140-150

Sigurdsson JB, Titman CW, Davies PA (1976) The dispersal of young post-larval bivalve mollusks by byssal threads. Nature 262:386-387

> Smith GK, Guichard F, Petrovic F, McKindsey C (2009) Using spatial statistics to infer scales of demographic connectivity between populations of the blue mussel, Mytilus spp. Limnol Oceanogr 54:970-977

Steffani CN, Branch GM (2005) Mechanisms and consequences of competition between an alien mussel, Mytilus galloprovincialis, and an indigenous limpet, Scutellastra argenvillei. J Exp Mar Biol Ecol 317:127-142

> Tapia FJ, Pineda J, Ocampo-Torres J, Fuchs HL, Parnell PE, Montero P, Ramos S (2004) High-frequency observations of wind-forced onshore transport at a coastal site in Baja California. Cont Shelf Res 24:1573-1585

Tapia FJ, Navarrete SA, Castillo M, Menge BA and others (2009) Thermal indices of upwelling effects on innershelf habitats. Prog Oceanogr 83:278-287

> Vargas C, Narváez D, Piñones A, Venegas RM, Navarrete SA (2004) Internal tidal bore warm fronts and settlement of invertebrates in central Chile. Estuar Coast Shelf Sci 61:603-612

> Wieters EA (2005) Upwelling control of positive interactions over mesoscales: a new link between bottom-up and topdown processes on rocky shores. Mar Ecol Prog Ser 301: 43-54

- Wieters EA, Kaplan DM, Navarrete SA, Sotomayor A, Largier J, Nielsen KJ, Véliz F (2003) Alongshore and temporal variability in chlorophyll a concentration in Chilean nearshore waters. Mar Ecol Prog Ser 249:93-105

Wieters EA, Salles E, Januario SM, Navarrete SA (2009) Refuge utilization and preferences between competing intertidal crab species. J Exp Mar Biol Ecol 374:37-44

Submitted: July 1, 2013; Accepted: November 7, 2014

Proofs received from author(s): January 11, 2015 